\title{
Towards a unified generic framework to define and observe contacts between livestock and wildlife: a systematic review
}

\author{
Sonny A Bacigalupo ${ }^{\text {Corresp., } 1}{ }^{\text {, Linda K Dixon }}{ }^{2}$, Simon Gubbins ${ }^{2}$, Adam J Kucharski ${ }^{3}$, Julian A Drewe ${ }^{1}$ \\ 1 Royal Veterinary College, Hatfield, United Kingdom \\ 2 The Pirbright Institute, Woking, Surrey, United Kingdom \\ 3 London School of Hygiene \& Tropical Medicine, University of London, London, United Kingdom \\ Corresponding Author: Sonny A Bacigalupo \\ Email address: sbacigalupo@rvc.ac.uk
}

Wild animals are the source of many pathogens of livestock and humans. Concerns about the potential transmission of economically important and zoonotic diseases from wildlife have led to increased surveillance at the livestock-wildlife interface. Knowledge of the types, frequency and duration of contacts between livestock and wildlife is necessary to identify risk factors for disease transmission and to design possible mitigation strategies. Observing the behaviour of many wildlife species is challenging due to their cryptic nature and avoidance of humans, meaning there are relatively few studies in this area. Further, a consensus on the definition of what constitutes a 'contact' between wildlife and livestock is lacking. A systematic review was conducted to investigate which livestock-wildlife contacts have been studied and why, as well as the methods used to observe each species. Over 30,000 publications were screened, of which 122 fulfilled specific criteria for inclusion in the analysis. The majority of studies examined cattle contacts with badgers or with deer; studies involving wild pig contacts with cattle or with domestic pigs were the next most frequent. There was a range of observational methods including motion-activated cameras and global positioning system collars. As a result of the wide variation and lack of consensus in the definitions of direct and indirect contacts, we developed a unified framework to define livestock-wildlife contacts that is sufficiently flexible to be applied to most wildlife and livestock species for non-vector-borne diseases. We hope this framework will help standardise the collection and reporting of contact data; a valuable step towards being able to compare the efficacy of wildlife-livestock observation methods. In doing so, it may aid the development of better disease transmission models and improve the design and effectiveness of interventions to reduce or prevent disease transmission. 


\section{Towards a unified generic framework to define and observe contacts between livestock and wildlife: a systematic review}

Sonny A. Bacigalupo ${ }^{1}$, Linda K. Dixon², Simon Gubbins ${ }^{2}$, Adam J. Kucharski ${ }^{3}$, Julian A. Drewe ${ }^{1}$

${ }^{1}$ Royal Veterinary College, University of London, Hatfield, UK

${ }^{2}$ The Pirbright Institute, Woking, Surrey, UK

${ }^{3}$ London School of Hygiene \& Tropical Medicine, University of London, London, UK

Corresponding Author

Sonny Bacigalupo ${ }^{1}$

Royal Veterinary College, Hawkshead Lane, Brookmans Park, Hatfield, AL9 7TA, UK

Email address: sbacigalupo@rvc.ac.uk 


\section{Abstract}

2 Wild animals are the source of many pathogens of livestock and humans. Concerns about the

3 potential transmission of economically important and zoonotic diseases from wildlife have led to

4 increased surveillance at the livestock-wildlife interface. Knowledge of the types, frequency and

5 duration of contacts between livestock and wildlife is necessary to identify risk factors for

6 disease transmission and to design possible mitigation strategies. Observing the behaviour of

7 many wildlife species is challenging due to their cryptic nature and avoidance of humans,

8 meaning there are relatively few studies in this area. Further, a consensus on the definition of

9 what constitutes a 'contact' between wildlife and livestock is lacking. A systematic review was

10 conducted to investigate which livestock-wildlife contacts have been studied and why, as well as

11 the methods used to observe each species. Over 30,000 publications were screened, of which 122

12 fulfilled specific criteria for inclusion in the analysis. The majority of studies examined cattle

13 contacts with badgers or with deer; studies involving wild pig contacts with cattle or with

14 domestic pigs were the next most frequent. There was a range of observational methods

15 including motion-activated cameras and global positioning system collars. As a result of the wide

16 variation and lack of consensus in the definitions of direct and indirect contacts, we developed a

17 unified framework to define livestock-wildlife contacts that is sufficiently flexible to be applied

18 to most wildlife and livestock species for non-vector-borne diseases. We hope this framework

19 will help standardise the collection and reporting of contact data; a valuable step towards being

20 able to compare the efficacy of wildlife-livestock observation methods. In doing so, it may aid

21 the development of better disease transmission models and improve the design and effectiveness

22 of interventions to reduce or prevent disease transmission. 


\section{Introduction}

24 The interface where livestock and wildlife may come into contact with each other is an area of

25 growing scientific interest, particularly as wildlife can act as a 'reservoir' for diseases of

26 livestock [1]. Disease transmission between livestock and wildlife can have marked economic

27 impact, such as African swine fever outbreaks in domestic pigs and wild boar (Sus scrofa) in

28 Europe and Asia [2], where the loss of $12-20 \%$ of the global pig herd in 2019 led to a $10 \%$

29 increase in the food price index of pork [3]. The impact of disease transmission on wildlife can

30 be seen in the loss of around half the global saiga (Saiga tatarica) antelope population in 2015 to

31 Pasteurella multocida, a pathogen harboured by livestock [4]. Contact between wildlife and

32 livestock may also lead to conflict between humans and wildlife, with compensation for large

33 carnivore predation and other damage costing 28.5 million euros annually in Europe [5]. The

34 proximity of agricultural land to wildlife habitats is a key factor in human-wildlife conflicts and

35 in the spill-over of pathogens from wildlife to livestock and humans [6]. The emergence of

36 diseases from wildlife that infect humans via livestock intermediaries, such as bat-borne Hendra

37 virus (affecting humans via horses) and Nipah virus (affecting humans via pigs) [7], further

38 highlight the importance of contacts between wildlife, livestock and people. These contacts are

39 seldom recorded, however, because many wildlife species are cryptic and therefore difficult to

40 observe, capture and sample.

41

42 Observing wildlife-livestock contacts is becoming easier with advances in remote technologies

43 such as motion-activated cameras, global positioning system (GPS) collars and proximity loggers

44 [8-10]. These methods are usually (but not always) used to monitor one species at a time. They

45 are not standardised, however, meaning there are many variations in monitoring protocols, often 
46 depending on basic practicalities such as battery life, people-hours, cost and the aims of the

47 study. The methods used to monitor livestock-wildlife contacts may influence (or be influenced

48 by) the kind of contact to be monitored, the context of the study and what the data will be used

49 for.

51 Livestock-wildlife contact data is needed to inform the simulation and modelling of diseases that

52 have multiple host species, but information on the types of contact needed for transmission and

53 the rates at which these occur is lacking [11]. Knowledge of livestock-wildlife contact data can

54 be used to identify risk factors and predict where these contacts are more or less likely to occur,

55 for example predicting the likelihood of badger (Meles meles) visits to cattle farms in the context

56 of bovine tuberculosis transmission [12]. It could also be used to implement and improve

57 mitigation strategies to prevent unwanted livestock-wildlife contacts. To mitigate wolf (Canis

58 lupus) predation on sheep, for example, the effectiveness of prevention programs needs to be

59 evaluated in ways that do not depend on livestock attacks alone, using methods such as GPS

60 monitoring of wolf movements around sheep farm bio-fences $[5,13]$. Similarly, the effectiveness

61 of measures taken to prevent disease transmission can also be evaluated such as by comparing

62 deer-cattle contact rates between farms with and without deer fences installed [14-16].

63 Knowledge of livestock-wildlife contacts can be used in these contexts to limit the economic loss

64 associated with disease and predation. Given these multiple ways of gathering and using

65 livestock-wildlife contact data, the definition of what constitutes a relevant contact will vary

66 depending on the aim of the study.

67 
68 In the context of disease transmission, defining contact is challenging and while types of contact

69 are often broadly grouped into being 'direct' or 'indirect', there are no standardised definitions

70 [17]. Direct contacts are usually thought of as representing physical contact or being in close

71 proximity over a short period of time, and so may include fighting, mating between feral and

72 domestic animals of the same species, or being face-to-face or nose-to-nose. Indirect contacts are

73 more difficult to define due to issues of long-distance aerosol transmission, environmental

74 persistence of pathogens in spores and fomites, and intermediate insect vectors [11]. Other

75 ecological definitions of livestock-wildlife contacts could also include avoidance behaviour or

76 competition for resources between species. This variation in definitions means it is difficult to

77 make meaningful comparisons between studies and to apply findings from one study to different

78 contexts. Therefore, a standardised generic template for defining livestock-wildlife contacts

79 would be useful.

80

81 The aim of this study was to systematically review the reasons for, and observational methods

82 used in, studies investigating livestock-wildlife contacts, and to propose a generalised framework

83 for defining contacts between livestock and wildlife. 


\section{Methods}

\section{Literature Search and Data Extraction}

86 We defined livestock as 'farmed domesticated mammals' [18], wild animals as 'free-ranging

87 non-domesticated mammals', and contact as 'activity implying an interaction or association

88 between species including the shared use of resources such as farmland'. The terms interaction

89 and contact were used synonymously within the literature, but contact is used here for

90 consistency. The systematic review question was "Which methods have been used to assess the

91 frequency of, and types of, contacts between wild animals and livestock or

92 livestock farms worldwide?".

93

94 Search terms for wildlife, livestock and type of contact were combined by the Boolean operators

'OR' and 'AND' to identify publications that investigated contact between any wild and

96 domestic mammal (Table S1). Search terms were based on common species names, and generic

97 terms such as 'feral', 'wildlife', 'livestock' and 'farm'. Searches were conducted in CAB

98 Abstracts, Scopus and Pubmed. CAB Abstracts is a comprehensive database of life science

99 research with broad coverage of veterinary literature in particular, and Scopus has a broad

100 coverage of interdisciplinary journals $[19,20]$.

101

102 Search results were consolidated into Microsoft Excel and duplicates were identified and

103 removed using queries followed by manual inspection. Titles, abstracts and full texts of the

104 retrieved publications were evaluated by SAB against pre-specified exclusion and inclusion

105 criteria (Table 1). Any papers for which the criteria were not clear were also evaluated by JAD.

106 In all such cases both authors agreed on the final decision. We wished to capture publications 
107 that collected, used or analysed data to investigate direct or indirect contacts between farmed

108 livestock and terrestrial wild mammals whose adult bodyweight is typically $>5 \mathrm{~kg}$. Specifically,

109 publications were included if they attempted to quantify, characterise, or identify risk factors for

110 livestock-wildlife contacts. Only articles in English and those accessible to researchers were

111 included. All reasonable efforts were made to access papers that passed abstract screening. We

112 excluded studies in which predation events were the sole indicator of livestock-wildlife contacts,

113 and studies of wild animals that were not free-living, were tamed or were relocated for the

114 purpose of the study. Publications until 11 November 2019 were included, and no time

115 restrictions were applied to the start of the search. Working definitions of direct and indirect

116 contact were developed before performing the literature search and used to avoid ambiguity

117 when evaluating publications for inclusion.

118

119 Direct contact was provisionally defined prior to reviewing the papers as physical contact

120 between at least one wild animal and one farm animal. Indirect contact was provisionally defined

121 as contact between at least one wild animal and a resource used by at least one farm animal

122 including, but not limited to, food, water and space. Therefore, studies that investigated wildlife

123 and livestock shared resource use, but did not explicitly investigate contacts, were included.

124 These definitions were used throughout the process of identifying and analysing the papers in

125 this review. Study data was extracted and livestock and wildlife species, observation methods

126 and definitions were categorised. Where available, the power of each study, defined as the

127 likelihood of detecting contacts, was recorded. Themes that emerged during data extraction were

128 grouped into seven broad study themes, namely behavioural, competition, conservation, disease,

129 human-wildlife conflict, methods papers and wildlife management (Fig. S1). Where studies had 
130 more than one theme, themes were subjectively allocated as dominant (primary) or secondary

131 based on the aims of the study. Results were visualised and plotted using R (version 3.6.3 [21])

132 and R packages listed in Table S2.

133 Development of a Generic Unified Framework

134 Following categorisation of definitions, a generic unified framework was developed by grouping

135 and identifying commonalities in definitions of 'direct' and 'indirect' contact, namely relating to

136 space and time. The spatial and temporal limits separating relevant contacts from inconsequential

137 contacts and non-contact events were identified for each study, and a framework was developed

138 based on defining contacts in relation to both space and time. Using this framework, relevant

139 contacts were defined using the parameters of critical space $\left(\mathrm{S}_{\mathrm{C}}\right)$ and critical time $\left(\mathrm{T}_{\mathrm{C}}\right)$. We

140 defined $\mathrm{S}_{\mathrm{C}}$ as the critical space (distance or area) between animals below which a contact

141 relevant to the study is considered to have occurred, and $\mathrm{T}_{\mathrm{C}}$ as the critical time window within

142 which a relevant contact is considered to have occurred. 


\section{Results}

144 During data categorisation and analyses, many publications were categorised into more than one

145 group due to studying multiple species, using multiple detection methods and having multiple

146 themes, and therefore the number of studies exceed $122(100 \%)$ in several instances reported

147 below.

149 Search results, quality appraisal and themes

150 A total of 43,032 papers were identified by the search terms across all three databases, of which

15130,080 were unique results. After screening using the exclusion and inclusion criteria in Table 1,

152122 publications remained in the final analysis (Fig. 1). Publication date ranged from 1980 to

153 2019, with 117 (96\%) published in the last 20 years (Fig. 2). Studies conducted in Europe, North

154 America and Africa made up 89\% of the results (Table S3) with the USA and UK producing the

155 most publications (21\% and $18 \%$, respectively).

156

157 Low study power was mentioned briefly in only $11(9 \%)$ publications and statistical power

158 calculations were not performed. The level of uncertainty was acknowledged in 64 (53\%)

159 publications.

160

161 Disease was the dominant theme and featured in 80 of 122 studies $(66 \%)$, followed by human-

162 wildlife conflict $(22 / 122 ; 18 \%)$, competition between wildlife and livestock (17/122; 14\%),

163 conservation $(16 / 122 ; 13 \%)$, wildlife management $(11 / 122 ; 9 \%)$, behavioural studies $(3 / 122 ; 2 \%)$

164 and methods validation (2/122; 2\%) (Fig. S1). Within the disease-themed papers, Mycobacterium

165 bovis was the most studied pathogen $(49 / 80 ; 61 \%)$ followed by foot-and-mouth disease virus 
$166(8 / 80 ; 10 \%)$ (Tables S4 and S5). Wildlife-cattle contacts were the focus of 98 of the 122 studies

$167(80 \%)$ and a further 22 studies (18\%) focussed on sheep, pigs, farmed deer and camelids. The

168 most studied wildlife species were deer (30/122; 25\%), wild pigs [including wild boar] (26/122;

$16921 \%)$ and badgers (25/122; 20\%: Fig. S2 and S3). The wildlife species were not specified in 11

170 papers, some of which studied wild ungulates competing for livestock grazing [22-24], others

171 that concerned wildlife as hosts of cattle diseases such as bovine tuberculosis [25-27] and foot-

172 and-mouth disease $[28,29]$, and the remainder that were completely unspecified.

\section{Methods used to observe livestock-wildlife contacts}

175 Methods that monitored both livestock and wildlife species were used in 88 publications (72\%)

176 whereas 34 studies (28\%) monitored wildlife only. Camera trapping was the most frequent

177 method of monitoring wildlife (37 studies, 31\%), and was most prominently used in badgers,

178 deer and wild pigs (Fig. 3). GPS collars were the second most used method to monitor wildlife

179 (29 studies, 24\%), and while they were also used predominantly on badgers, deer and wild pigs,

180 they were used proportionally more than cameras to monitor predators such as big cats and

181 wolves and large herbivores such as buffalo, wild horses and elephants. Other methods used to

182 monitor wildlife were direct visualisation $(21 ; 17 \%)$, farmer questioning $(20 ; 16 \%)$, radio-

183 transmitters $(17 ; 14 \%)$, activity signs $(15 ; 12 \%)$ and proximity loggers $(7 ; 6 \%)$. Some studies

184 utilised more than one observation method, and therefore the numbers of studies exceed 122

185 (100\%) Studies that monitored livestock tended to use the same methods as for wildlife, although

18610 studies dedicated fewer resources to monitor livestock; for example [30] used GPS collars to

187 monitor wild deer and farmer questioning to monitor cattle behaviour. Studies that did not

188 monitor livestock tended to infer wildlife-livestock contact from monitoring only the activities of 
189 wildlife on or around livestock holdings, such as on pasture, in buildings and the shared use of

190 resources such as livestock feed.

191

192 A variety of methods were used to observe different types of contact data (Fig. S4). Methods

193 such as GPS collars and radio-tracking (telemetry) were used to collect the locations of wildlife

194 (e.g. $[10,31,32])$, whereas proximity loggers were used to detect close proximity contacts

195 between livestock and wildlife or with postulated high-risk disease transmission areas such as

196 badger latrines (e.g. [9]). Camera traps and direct visualisation were used to observe behavioural

197 activity, such as nose-to-nose contacts between cattle and badgers [33], foxes taking piglets from

198 farrowing huts [34] and wild boar eating from cattle troughs [35]. Some methods were used to

199 detect the presence of wild animals on farms or on pasture only, such as surveys of activity signs

200 to detect wild boar rooting on sheep pasture [36] and GPS collars to demonstrate the avoidance

201 of livestock pasture by lions [37]. Thirty studies combined more than one method to monitor

202 wildlife, such as [38] which combined activity signs, GPS collar data and camera traps to

203 monitor feral swine activity at and around domestic pig pens. The majority of studies, however,

204 used only one method and were able to collect information about the type of contact defined by

205 the study.

206

207 Definitions of direct and indirect contacts

208 Definitions for both direct contact and indirect contact were provided by 27 studies, with a

209 further four defining direct contact only and 54 defining indirect contact only (Table 2; Table 3).

210 Definitions of direct contact tended to focus on the spatial distance between wildlife and

211 livestock at one point in time (Table 2). Definitions of indirect contact tended to focus on the use 
212 of space or resources by wildlife in a location previously or subsequently occupied by livestock,

213 within a certain time frame (Table 3). There were some variations to these trends: two studies

214 specified a time frame longer than one time point to define direct contact $[15,39]$. The amount of

215 time was usually determined by the context of the study, such as the survival time of a specified

216 pathogen in the environment, known as the critical time window of a contact [40]. Contacts were

217 also defined in 15 studies as the shared use of resources between livestock and wildlife, such as

218 feed and water. There were large variations between studies in the defined distances and time

219 windows, with direct contact distances ranging from physical contact (seven studies) to within

220120 metres of each other (one study), and indirect definitions ranging from within the same

221 camera image (two studies) to within 50 kilometres of a location (one study). There was less

222 variation in definitions between studies with similar contexts and aims. For example, among $M$.

223 bovis transmission studies in cattle and badgers, the definition of direct contact ranged from

224 physical contact to within two metres (six studies), and indirect contacts were defined as

225 presence on farmland, sharing of resources and visits to badger latrines by cattle (20 studies).

226 Importantly, no definition of contact was provided in 25 studies (44\%) that reported direct

227 contacts, and 34 studies (29\%) that reported indirect contacts.

228

229 Regardless of the contact definitions or methods used to observe contacts, direct contacts were

230 detected much less frequently than indirect contacts. For example, one study [15] found no

231 instances of cattle within two metres of deer, compared to over 40,000 indirect contacts of deer

232 with cattle via shared feed. Overall, the median number of direct contacts between wildlife and

233 livestock was in single figures, whereas the median number of indirect contacts occurred in the

234 order of hundreds or even thousands (Table 4). Low study power was acknowledged, but not 
235 calculated, by 11 studies (9\%), and is likely to be a feature of many more which did not report it.

236 No studies reported adequate power. The low power of studies to observe rare contacts, coupled

237 with the variation in, or lack of, contact definitions, makes it very difficult to compare the

238 effectiveness of the methods used to observe wildlife-livestock contacts.

Proposed unified framework to define direct and indirect contacts

241 Space (area or distance between animals) and time were crucial components of the varied

242 definitions of direct and indirect contact in this review. In an effort to unify these parameters, a

243 novel generic framework to categorise wildlife-livestock contacts is proposed in Fig. 4, based on

244 the locations of individuals in space and time. Using this framework, we propose that the contact

245 type (direct or indirect) is defined using the two parameters $\mathrm{S}_{\mathrm{C}}$ and $\mathrm{T}_{\mathrm{C}}$. Multiple critical

246 thresholds can be used within the framework to differentiate between definitions of direct contact

$247\left(\mathrm{~S}_{\mathrm{C} 1}\right.$ and $\left.\mathrm{T}_{\mathrm{C} 1}\right)$ and indirect contact $\left(\mathrm{S}_{\mathrm{C} 2}\right.$ and $\left.\mathrm{T}_{\mathrm{C} 2}\right)$. For a direct contact to occur, two individuals are

248 within the same pre-specified critical space (distance or area: $\mathrm{S}_{\mathrm{C} 1}$ ) within a pre-specified critical

249 time window $\left(\mathrm{T}_{\mathrm{C} 1}\right)$. Similarly, for an indirect contact to occur, animals are within another pre-

250 specified critical space $\left(\mathrm{S}_{\mathrm{C} 2}\right)$ within another pre-specified critical time window $\left(\mathrm{T}_{\mathrm{C} 2}\right)$. The reader

251 is directed to Fig. 4 for examples from the literature of possible combinations of $\mathrm{S}_{\mathrm{C}}$ and $\mathrm{T}_{\mathrm{C}}$. $\mathrm{T}_{\mathrm{C} 2}$

252 may be the same as $\mathrm{T}_{\mathrm{C} 1}$ (if $\mathrm{S}_{\mathrm{C} 2}$ is larger than $\mathrm{S}_{\mathrm{C} 1}$ : compare example $\mathrm{A}$ with example $\mathrm{B}$ in Figure

253 4) or $\mathrm{T}_{\mathrm{C} 2}$ may be different from $\mathrm{T}_{\mathrm{C} 1}$ (in which case $\mathrm{T}_{\mathrm{C} 2}$ will usually, but not always, be larger

254 than $\mathrm{T}_{\mathrm{C} 1}$ : compare example A with examples $\mathrm{C}, \mathrm{D}, \mathrm{E}$ and $\mathrm{F}$ in Figure 4). Similarly, $\mathrm{S}_{\mathrm{C} 2}$ may be

255 the same as $\mathrm{S}_{\mathrm{C} 1}$ (if $\mathrm{T}_{\mathrm{C} 2}$ is larger than $\mathrm{T}_{\mathrm{C} 1}$ : compare example $\mathrm{A}$ with examples $\mathrm{C}$ and $\mathrm{E}$ in Figure

256 4) or $\mathrm{S}_{\mathrm{C} 2}$ may be different from $\mathrm{S}_{\mathrm{C} 1}$ (in which case $\mathrm{S}_{\mathrm{C} 2}$ will usually, but not always, be larger than

$257 \mathrm{~S}_{\mathrm{C} 1}$ : compare example A with examples B, D and $\mathrm{F}$ in Figure 4). Same, near and different are 
258 used here to illustrate spatial and temporal differences between examples. These terms are

259 relative and will vary along with $\mathrm{S}_{\mathrm{C}}$ and $\mathrm{T}_{\mathrm{C}}$ depending on the system being studied, the

260 objectives of the study and other factors such as host behaviour and the biology of the pathogen,

261 in the case of disease studies; therefore, values for $\mathrm{T}_{\mathrm{C} 1}, \mathrm{~T}_{\mathrm{C} 2}, \mathrm{~S}_{\mathrm{C} 1}$ and $\mathrm{S}_{\mathrm{C} 2}$ should be decided in

262 advance of a study being conducted, and they should be clearly reported when data are

263 presented.

264

265 Although the exact values of the critical distance between animals and the critical time window

266 over which this happens will depend on the system being studied as well as the specific

267 objectives of each study, the adoption of this generic framework to define direct and indirect

268 contacts will help identify studies with similar definitions where results are more easily

269 comparable. 


\section{Discussion}

\section{The need for a generic unified framework}

272 This review has found that definitions of contact are wide-ranging and highly dependent on the

273 context of the study. Definitions can vary depending on the species and demographics of the

274 wildlife and livestock involved, the methods used to detect contacts and the system being studied

275 such as the environmental conditions and pathogen characteristics in studies where contacts are

276 representative of disease transmission. Definitions of direct contact were extremely diverse,

277 ranging from direct physical contact to animals being merely within a hundred metres of each

278 other. Indirect contact ranged from animals sharing resources, being within five kilometres of

279 each other or overlapping in home ranges, and the time window that these events occurred in

280 varied from hours to weeks.

281

282 The aim of this generic unified framework is to promote consistent reporting of definitions of contacts enabling comparisons to be made between the approaches of wildlife-livestock contact

284 studies, regardless of the species or pathogen studied or the context of the study. This is needed

285 because our systematic review found that while wildlife-livestock contact data was collected in

286 terms of space and time, some studies omitted space or time in their definitions, or there was a

287 complete lack of a definition. Conflicting and overlapping definitions of direct and indirect

288 contact were also identified. Making any sort of meaningful comparison between such studies is

289 challenging. For example it is difficult to assess what, if any, implications there are for deer-

290 cattle disease transmission from a behavioural study showing deer avoid cattle despite similar

291 habitat preferences [41], without knowing what types of contact (e.g., direct or indirect; what 
292 specific types) were likely to be meaningful. It is even difficult to compare studies within the

293 same system, for example establishing the relevance of cattle-badger contacts for bovine

294 tuberculosis transmission when some studies define a contact as 'presence on farm' [42, 43] and

295 others define it as 'presence in buildings', and neither study defines the time window. Use of the

296 generic unified framework would enable consistent reporting of definitions between studies and

297 is an important step if the results of wildlife-livestock contact studies are to be comparable.

298

299

Applications of a generic unified framework

300 Models that incorporate empirical rather than theoretical information on the frequency and

301 duration of contacts important for disease transmission are more likely to be useful for disease

302 mitigation [11]. The use of a standardised definition framework in future studies of livestock-

303 wildlife contacts would enable consistency in datasets and enable the retrospective selection of

304 contact data relevant to a particular model, which could then be incorporated in a similar way to

305 the data used in recent bovine tuberculosis transmission models [16, 44]. The generic unified

306 framework proposed in this current paper could also be useful in designing livestock-wildlife

307 contact studies, since defining the type of contact to be detected - in addition to practical

308 considerations, such as an area's signal strength affecting the viability of GPS device use - helps

309 with the choice of detection method. The framework is also flexible and applicable to different

310 contexts, species and diseases since it allows for the variation in definitions seen in this review,

311 and it is hoped it will broaden the range of future livestock-wildlife contact studies.

312

313 To resolve human-wildlife conflicts usually requires robust livestock-wildlife contact studies. At

314 least 120 studies that only used predation events to infer livestock-wildlife contacts were 
315 excluded from the review, yet predators - particularly wolves - were the second most commonly

316 studied group of wild mammals. Given that predation studies appear to form a large proportion

317 of wildlife-livestock contact studies, this is an area where adoption of the generic framework

318 could help design meaningful contact studies to evaluate preventive measures without relying

319 solely on predation events.

320

\section{1}

\section{Further development of the generic unified framework}

322 The generic unified framework does not provide an overall consensus on definitions of direct and

323 indirect contact, but does provides a structure with which to start this process. While using the

324 generic unified framework provides a standardised definition of contact in time and space,

325 identifying the types of contact that are relevant to the study, and thus the values of $\mathrm{S}_{\mathrm{C}}$ and $\mathrm{T}_{\mathrm{C}}$,

326 will vary depending on the objectives and context of each study. While a universally accepted set

327 of definitions for contacts is difficult to devise, we hope that by defining Sc and Tc here we will

328 encourage the start of the debate around (and between) studies of similar contexts, and perhaps

329 then acceptable ranges for these values will emerge. Developing a framework for deriving $\mathrm{S}_{\mathrm{C}}$ an

$330 \mathrm{~T}_{\mathrm{C}}$, based upon the species studied, environment, pathogen and methodology is beyond the scope

331 of this review, and would be a necessary next step so that wildlife-livestock contact rates could

332 be comparable between studies of similar contexts. For example, for disease studies, it would be

333 advisable that $\mathrm{S}_{\mathrm{C}}$ and $\mathrm{T}_{\mathrm{C}}$ were based on values below which transmission is likely to occur, such

334 as aerosol dispersion distance and environmental survivability. For any system, there may be a

335 range of appropriate values for $\mathrm{S}_{\mathrm{C}}$ and $\mathrm{T}_{\mathrm{C}}$.

336 
337 The generic unified framework presented in this paper is a step towards being able to compare

338 observation methods and contact data in order to standardise and evaluate different monitoring

339 methods. This is important as our systematic review revealed that the methods used to observe

340 livestock-wildlife contacts to date have often had low detection rates and therefore been of low

341 power due to the difficulty of monitoring cryptic wildlife species, and the rarity of some types of

342 wildlife-livestock contacts, particularly direct contacts. Further considerations for the

343 comparison of observation methods are the representativeness of individuals monitored,

344 especially with methodologies that require the marking of individuals such as GPS and proximity

345 loggers, and a standardised system for relativizing the number of contacts with regards to the

346 total observation effort. For example, two studies will not be comparable if study A only uses 3

347 camera traps and study B uses 100 camera traps, or if study C collects GPS locations every hour

348 when study D collects only one GPS fix per day. Reporting representativeness of individuals and

349 relativizing contact rates in terms of total population will go some way to establishing the power

350 of wildlife-contact studies. Furthermore, it may be useful for studies to indicate the detection

351 limits of the methodology used, in terms of space and time.

352 Scope of existing wildlife-livestock contact studies

353 This review has identified the narrow scope and limited geographic range of livestock-wildlife

354 contact studies, which means the data summarised in this review should not be considered

355 representative of all wildlife-livestock contacts worldwide. The majority of studies focussed on

356 cattle-wildlife contacts and diseases of cattle. Bovine tuberculosis (infection with M. bovis)

357 featured prominently, indicative of the economic and potentially zoonotic importance of this

358 disease to the USA and UK, where the most livestock-wildlife contact studies were conducted

$359[45,46]$. Foot-and-mouth-disease was the most studied viral pathogen and this is most likely 
360 explained by its broad geographical spread and high economic impact [47]. This demonstrates

361 the human-centric view of the wildlife-livestock interface, with most focus on the impacts on

362 humans and domestic animals, and very little (if any) focus on the value of wildlife [48]. There

363 were, however, some livestock-wildlife contact studies of high impact conservation importance

364 such as infection with Mannheimia spp. in bighorn sheep (Ovis canadensis) and Pasteurella spp.

365 in saiga antelope [49-51]. If we are to collect more (and better) wildlife-livestock contact data

366 that include a broader range of species and contexts, careful consideration must be used when

367 selecting the most effective and practical observational method for monitoring cryptic wildlife

368 species.

369

370 This review highlights that observing contacts between multiple species is possible and can yield

371 high quality information. Increasing the efficiency of monitoring methods would justify their use

372 for more applications. Health surveillance systems at livestock-wildlife interfaces have been

373 suggested as a method to detect and control emerging diseases along with preventing contact

374 between wildlife and livestock [52]. Preventing high-risk contacts may be more cost-effective

375 than surveillance, but the effectiveness of prevention strategies will need to be evaluated by

376 monitoring contacts, or lack thereof. More efficient monitoring will also allow for quantitative

377 risk assessments of wildlife-livestock contacts which are presently difficult to conduct due to a

378 limited understanding of potential contacts leading to pathogen transmission [53]. Some

379 observation methods such as camera traps are likely to have the ability to identify new potential

380 transmission routes between livestock and wildlife (e.g., the use of cattle salt licks by racoons

381 [26]), and may identify livestock-wildlife contacts previously not considered (e.g., observing

382 farm visits by foxes during a study focussing on badgers [54]). Identifying wildlife species that 
383 may be the origin of rapidly emerging human diseases is a priority to prevent future pandemics

384 [55]. In situations where human infections are mediated by livestock, rapid implementation of

385 observational methods to detect contacts between wildlife and livestock could more quickly

386 identify wildlife hosts and risky behaviours. In order to determine the efficiency and efficacy of

387 different observational methods, the methods used and data collected by them must be

388 comparable, hence the need for a unified framework.

389 Limitations of this review

390 Our study has some limitations which we summarise here. At present, our generic unified

391 framework does not explicitly account for disease transmission via vectors or fomites, although

392 the latter will to some extent be captured within our definition of indirect contact. In order that

393 observation methods were likely to be comparable between species, we focussed on terrestrial

394 mammals so did not address diseases primarily hosted by birds or bats such as avian influenza,

395 Nipah virus and Hendra virus. Small terrestrial mammals $(<5 \mathrm{~kg})$ were also not included for this

396 reason, and because a disproportionate number of rodent studies focus on their roles as

397 laboratory animals or farm pests, and not on contacts with livestock. While the generic unified

398 framework may be applicable to these types of wildlife, it is unclear which observational

399 methods seen in this review would be most effective or efficient, and the conclusions drawn from

400 this review may not be reflective of systems that involve other taxa .

401 Conclusion

402 As human populations continue to expand and agriculture encroaches further on wildlife

403 habitats, disease spill-over (in both directions) between wildlife, livestock and humans is

404 becoming more frequent [1]. As a result, the study of contacts between livestock and wildlife is

405 receiving ever increasing attention. This systematic review of the observational methods used to 
406 study contacts, and the subsequent proposal of a generic unified framework for defining contacts,

407 are two steps towards ensuring that data are collected and reported in a standardised way at a 408 time of increasingly urgent need. 
409 Acknowledgements

410 RVC manuscript number PPS_02151. 


\section{References}

412 1. Wiethoelter, A.K., D. Beltrán-Alcrudo, R. Kock, and S.M. Mor, Global trends in 413 infectious diseases at the wildlife-livestock interface. Proceedings of the National $414 \quad$ Academy of Sciences, 2015. 112(31): p. 9662-9667.

415 2. Dixon, L.K., K. Stahl, F. Jori, L. Vial, and D.U. Pfeiffer, African Swine Fever $416 \quad$ Epidemiology and Control. Annual review of animal biosciences, 2019. 8.

417 3. Pitts, N. and T. Whitnall, Impact of African swine fever on global markets. $418 \quad$ Agricultural Commodities, 2019. 9(3): p. 52.

419 4. Fereidouni, S., G.L. Freimanis, M. Orynbayev, P. Ribeca, J. Flannery, D.P. King, 420

421

431

6. Jones, B.A., D. Grace, R. Kock, S. Alonso, J. Rushton, M.Y. Said, D. McKeever, F. Mutua, J. Young, and J. McDermott, Zoonosis emergence linked to agricultural intensification and environmental change. Proceedings of the National Academy of Sciences, 2013. 110(21): p. 8399-8404.

7. Field, H., P. Young, J.M. Yob, J. Mills, L. Hall, and J. Mackenzie, The natural history of Hendra and Nipah viruses. Microbes and infection, 2001. 3(4): p. 307314.

8. Böhm, M., M.R. Hutchings, and P.C.L. White, Contact networks in a wildlifelivestock host community: identifying high-risk individuals in the transmission of bovine TB among badgers and cattle. PLoS ONE, 2009(No.April): p. e5016.

9. Drewe, J.A., H.M. O'Connor, N. Weber, R.A. McDonald, and R.J. Delahay, Patterns of direct and indirect contact between cattle and badgers naturally infected with tuberculosis. Epidemiology and Infection, 2013. 141(7): p. 14671475.

10. Barasona, J.A., M.C. Latham, P. Acevedo, J.A. Armenteros, A.D.M. Latham, C. Gortazar, F. Carro, R.C. Soriguer, and J. Vicente, Spatiotemporal interactions between wild boar and cattle: implications for cross-species disease transmission. Veterinary Research, 2014. 45(122): p. (12 December 2014).

11. Craft, M.E., Infectious disease transmission and contact networks in wildlife and livestock. Philosophical Transactions of the Royal Society B: Biological Sciences, 2015. 370(1669): p. 20140107. 
447 12. Robertson, A., J. Judge, G. Wilson, I.J. Vernon, R.J. Delahay, and R.A.

448

449

450

451

452

453

454

455

456

457

458

459

460

461

462

463

464

465

466

467

468

469

470

471

472

473

474

475

476

477

478

479

480

481 McDonald, Predicting badger visits to farm yards and making predictions available to farmers. PloS one, 2019. 14(5).

13. Ausband, D.E., M.S. Mitchell, S.B. Bassing, and C. White, No trespassing: Using a biofence to manipulate wolf movements. Wildlife Research, 2013. 40(3): p. 207216.

14. Lavelle, M.J., C.I. Henry, K. LeDoux, P.J. Ryan, J.W. Fischer, K.M. Pepin, C.R. Blass, M.P. Glow, S.E. Hygnstrom, and K.C. VerCauteren, Deer response to exclusion from stored cattle feed in Michigan, USA. Preventive veterinary medicine, 2015. 121(1-2): p. 159-164.

15. Lavelle, M.J., S.L. Kay, K.M. Pepin, D.A. Grear, H. Campa, III, and K.C. VerCauteren, Evaluating wildlife-cattle contact rates to improve the understanding of dynamics of bovine tuberculosis transmission in Michigan, USA. Preventive Veterinary Medicine, 2016. 135: p. 28-36.

16. Wilber, M.Q., K.M. Pepin, H. Campa III, S.E. Hygnstrom, M.J. Lavelle, T. Xifara, K.C. VerCauteren, and C.T. Webb, Modelling multi-species and multi-mode contact networks: Implications for persistence of bovine tuberculosis at the wildlife-livestock interface. Journal of Applied Ecology, 2019. 56(6): p. 14711481.

17. Eames, K., S. Bansal, S. Frost, and S. Riley, Six challenges in measuring contact networks for use in modelling. Epidemics, 2015. 10: p. 72-77.

18. FAO. Livestock Statistics - Concepts, Definitions and Classifications. 2020 [cited 2020 26th February 2020]; Available from: http://www.fao.org/economic/thestatistics-division-ess/methodology/methodology-systems/livestock-statisticsconcepts-definitions-and-classifications/en/.

19. Grindlay, D.J.C., M.L. Brennan, and R.S. Dean, Searching the Veterinary Literature: A Comparison of the Coverage of Veterinary Journals by Nine Bibliographic Databases. Journal of Veterinary Medical Education, 2012. 39(4): p. 404-412.

20. Aghaei Chadegani, A., H. Salehi, M. Yunus, H. Farhadi, M. Fooladi, M. Farhadi, and N. Ale Ebrahim, A comparison between two main academic literature collections: Web of Science and Scopus databases. Asian Social Science, 2013. 9(5): p. 18-26.

21. R Core Team, $R$ : A language and environment for statistical computing. 2020, $\mathrm{R}$ Foundation for Statistical Computing: Vienna, Austria. 
482 22. Mizutani, F., M. Kadohira, and B. Phiri, Livestock-wildlife joint land use in dry

483

484

485

486

487

488

489

490

491

492

493

494

495

496

497

498

499

500

501

502

503

504

505

506

507

508

509

510

511

512

513

514

515

516

517

lands of Kenya: a case study of the Lolldaiga Hills ranch. Animal Science Journal, 2012. 83(6): p. 510-516.

23. Sitters, J., I.M.A. Heitkönig, M. Holmgren, and G.S.O. Ojwang, Herded cattle and wild grazers partition water but share forage resources during dry years in East African savannas. Biological Conservation, 2009. 142(4): p. 738-750.

24. Crawford, C.L., Z.M. Volenec, M. Sisanya, R. Kibet, and D.I. Rubenstein, Behavioral and Ecological Implications of Bunched, Rotational Cattle Grazing in East African Savanna Ecosystem. Rangeland Ecology \& Management, 2019. 72(1): p. 204-209.

25. Munyeme, M., J.B. Muma, H.M. Munang'andu, C. Kankya, E. Skjerve, and M. Tryland, Cattle owners' awareness of bovine tuberculosis in high and low prevalence settings of the wildlife-livestock interface areas in Zambia. BMC Veterinary Research, 2010. 6(21): p. (20 April 2010).

26. Witmer, G., A.E. Fine, J. Gionfriddo, M. Pipas, K. Shively, K. Piccolo, and P. Burke, Epizootiologic survey of Mycobacterium bovis in wildlife and farm environments in northern Michigan. Journal of Wildlife Diseases, 2010. 46(2): p. 368-378.

27. Katale, B.Z., E.V. Mbugi, E.D. Karimuribo, J.D. Keyyu, S. Kendall, G.S. Kibiki, P. Godfrey-Faussett, A.L. Michel, R.R. Kazwala, P.v. Helden, and M.I. Matee, Prevalence and risk factors for infection of bovine tuberculosis in indigenous cattle in the Serengeti ecosystem, Tanzania. BMC Veterinary Research, 2013. 9(267): p. (30 December 2013).

28. Brahmbhatt, D.P., G.T. Fosgate, E. Dyason, C.M. Budke, B. Gummow, F. Jori, M.P. Ward, and R. Srinivasan, Contacts between domestic livestock and wildlife at the Kruger National Park Interface of the Republic of South Africa. Preventive Veterinary Medicine, 2012. 103(1): p. 16-21.

29. Molla, B., G. Ayelet, Y. Asfaw, Y. Jibril, and E. Gelaye, Participatory epidemiology and associated risk factors of foot-and-mouth disease in cattle in South Omo zone, South-Western Ethiopia. J. Vet. Med. Anim. Health, 2013. 5(11): p. 322-328.

30. Pruvot, M., D. Seidel, M.S. Boyce, M. Musiani, A. Massolo, S. Kutz, and K. Orsel, What attracts elk onto cattle pasture? Implications for inter-species disease transmission. Preventive Veterinary Medicine, 2014. 117(2): p. 326-339.

31. Raizman, E.A., H.B. Rasmussen, L.E. King, F.W. Ihwagi, and I. DouglasHamilton, Feasibility study on the spatial and temporal movement of Samburu's 
518

519

520

521

522

523

524

525

526

527

528

529

530

531

532

533

534

535

536

537

538

539

540

541

542

543

544

545

546

547

548

549

550

551

552

553

cattle and wildlife in Kenya using GPS radio-tracking, remote sensing and GIS. Preventive Veterinary Medicine, 2013. 111(01-Feb): p. 76-80.

32. Cooper, S.M., H.L. Perotto-Baldivieso, M.K. Owens, M.G. Meek, and M. Figueroa-Pagán, Distribution and interaction of white-tailed deer and cattle in a semi-arid grazing system. Agriculture, Ecosystems \&amp// Environment, 2008. 127(01-Feb): p. 85-92.

33. Tolhurst, B.A., R.J. Delahay, N.J. Walker, A.I. Ward, and T.J. Roper, Behaviour of badgers (Meles meles) in farm buildings: opportunities for the transmission of Mycobacterium bovis to cattle? Applied Animal Behaviour Science, 2009. 117(01-Feb): p. 103-113.

34. Fleming, P.A., S.J. Dundas, Y.Y.W. Lau, and J.R. Pluske, Predation by red foxes (Vulpes vulpes) at an outdoor piggery. Animals, 2016. 6(10): p. 60.

35. Kukielka, E., J.A. Barasona, C.E. Cowie, J.A. Drewe, C. Gortazar, I. Cotarelo, and J. Vicente, Spatial and temporal interactions between livestock and wildlife in South Central Spain assessed by camera traps. Preventive Veterinary Medicine, 2013. 112(03-Apr): p. 213-221.

36. Guillermo Bueno, C., I.C. Barrio, R. García-González, C.L. Alados, and D. Gómez-García, Does wild boar rooting affect livestock grazing areas in alpine grasslands? European Journal of Wildlife Research, 2010. 56(5): p. 765-770.

37. Oriol-Cotterill, A., D.W. Macdonald, M. Valeix, S. Ekwanga, and L.G. Frank, Spatiotemporal patterns of lion space use in a human-dominated landscape. Animal Behaviour, 2015. 101: p. 27-39.

38. Wyckoff, A.C., S.E. Henke, T.A. Campbell, D.G. Hewitt, and K.C. VerCauteren, Movement and habitat use of feral swine near domestic swine facilities. Wildlife Society Bulletin, 2012. 36(1): p. 130-138.

39. Cooper, S.M., H.M. Scott, G.R.d.1. Garza, A.L. Deck, and J.C. Cathey, Distribution and interspecies contact of feral swine and cattle on rangeland in South Texas: implications for disease transmission. Journal of Wildlife Diseases, 2010. 46(1): p. 152-164.

40. Cowie, C.E., M.R. Hutchings, J.A. Barasona, C. Gortázar, J. Vicente, and P.C.L. White, Interactions between four species in a complex wildlife: livestock disease community: implications for Mycobacterium bovis maintenance and transmission. European Journal of Wildlife Research, 2016. 62(1): p. 51-64.

41. Mattiello, S., W. Redaelli, C. Carenzi, and C. Crimella, Effect of dairy cattle husbandry on behavioural patterns of red deer (Cervus elaphus) in the Italian Alps. Applied Animal Behaviour Science, 2002. 79(4): p. 299-310. 
554 42. Mullen, E.M., T. MacWhite, P.K. Maher, D.J. Kelly, N.M. Marples, and M. Good,

555

556

557

558

559

560

561

562

563

564

565

566

567

568

569

570

571

572

573

574

575

576

577

578

579

580

581

582

583

584

585

586

587

588 The avoidance of farmyards by European badgers Meles meles in a medium density population. Applied Animal Behaviour Science, 2015. 171: p. 170-176.

43. Sleeman, D.P., J. Davenport, and A. Fitzgerald, Incidence of visits by badgers to farmyards in Ireland in winter. Veterinary Record, 2008. 163(24): p. 724.

44. Silk, M.J., J.A. Drewe, R.J. Delahay, N. Weber, L.C. Steward, J. WilsonAggarwal, M. Boots, D.J. Hodgson, D.P. Croft, and R.A. McDonald, Quantifying direct and indirect contacts for the potential transmission of infection between species using a multilayer contact network. Behaviour, 2018. 155(7-9): p. 731757.

45. De la Rua-Domenech, R., Human Mycobacterium bovis infection in the United Kingdom: incidence, risks, control measures and review of the zoonotic aspects of bovine tuberculosis. Tuberculosis, 2006. 86(2): p. 77-109.

46. O'Brien, D.J., S.M. Schmitt, S.D. Fitzgerald, and D.E. Berry, Management of bovine tuberculosis in Michigan wildlife: current status and near term prospects. Veterinary microbiology, 2011. 151(1-2): p. 179-187.

47. Knight-Jones, T. and J. Rushton, The economic impacts of foot and mouth disease-What are they, how big are they and where do they occur? Preventive veterinary medicine, 2013. 112(3-4): p. 161-173.

48. Chardonnet, P., B.d. Clers, J. Fischer, R. Gerhold, F. Jori, and F. Lamarque, The value of wildlife. Revue scientifique et technique-Office international des épizooties, 2002. 21(1): p. 15-52.

49. Clifford, D.L., B.A. Schumaker, T.R. Stephenson, V.C. Bleich, M.L. Cahn, B.J. Gonzales, W.M. Boyce, and J.A.K. Mazet, Assessing disease risk at the wildlifelivestock interface: a study of Sierra Nevada bighorn sheep. Biological Conservation, 2009. 142(11): p. 2559-2568.

50. O'brien, J.M., C.S. O'brien, C. McCarthy, and T.E. Carpenter, Incorporating foray behavior into models estimating contact risk between bighorn sheep and areas occupied by domestic sheep. Wildlife Society Bulletin, 2014. 38(2): p. 321-331.

51. Beauvais, W., S. Zuther, C. Villeneuve, R. Kock, and J. Guitian, Rapidly assessing the risks of infectious diseases to wildlife species. Royal Society open science, 2019. 6(1): p. 181043.

52. Gortazar, C., I. Diez-Delgado, J.A. Barasona, J. Vicente, J. De La Fuente, and M. Boadella, The wild side of disease control at the wildlife-livestock-human interface: a review. Frontiers in veterinary science, 2015. 1: p. 27. 
589 53. Miller, R.S., M.L. Farnsworth, and J.L. Malmberg, Diseases at the livestock-

590

591

592

593

594

595

596

597

598

599

600

601

602

603

604

605

606

607

608

609

610

611

612

613

614

615

616

617

618

619

620

621

622

623

624

625 wildlife interface: status, challenges, and opportunities in the United States.

Preventive veterinary medicine, 2013. 110(2): p. 119-132.

54. O'Mahony, D.T., Multi-species visit rates to farmyards: implications for biosecurity. Veterinary Journal, 2015. 203(1): p. 126-128.

55. Morse, S.S., J.A. Mazet, M. Woolhouse, C.R. Parrish, D. Carroll, W.B. Karesh, C. Zambrana-Torrelio, W.I. Lipkin, and P. Daszak, Prediction and prevention of the next pandemic zoonosis. The Lancet, 2012. 380(9857): p. 1956-1965.

56. Brook, R.K., E.v. Wal, F.M.v. Beest, and S.M. McLachlan, Evaluating use of cattle winter feeding areas by elk and white-tailed deer: implications for managing bovine tuberculosis transmission risk from the ground up. Preventive Veterinary Medicine, 2013. 108(02-Mar): p. 137-147.

57. Hockings, K.J., T. Humle, S. Carvalho, and T. Matsuzawa, Chimpanzee interactions with nonhuman species in an anthropogenic habitat. Behaviour, 2012. 149(03-Apr): p. 299-324.

58. Campbell, E.L., A.W. Byrne, F.D. Menzies, K.R. McBride, C.M. McCormick, M. Scantlebury, and N. Reid, Interspecific visitation of cattle and badgers to fomites: A transmission risk for bovine tuberculosis? Ecology and Evolution, 2019. 9(15): p. 8479-8489.

59. Tolhurst, B.A., A.I. Ward, and R.J. Delahay, A study of fox (Vulpes vulpes) visits to farm buildings in Southwest England and the implications for disease management. European Journal of Wildlife Research, 2011. 57(6): p. 1227-1230.

60. Vercauteren, K.C., M.J. Lavelle, N.W. Seward, J.W. Fischer, and G.E. Phillips, Fence-line contact between wild and farmed cervids in Colorado: potential for disease transmission. Journal of Wildlife Management, 2007. 71(5): p. 1594-1602.

61. Vercauteren, K.C., M.J. Lavelle, N.W. Seward, J.W. Fischer, and G.E. Phillips, Fence-line contact between wild and farmed white-tailed deer in Michigan: potential for disease transmission. Journal of Wildlife Management, 2007. 71(5): p. 1603-1606.

62. Jori, F., A. Relun, B. Trabucco, F. Charrier, O. Maestrini, D. Chavernac, D. Cornelis, F. Casabianca, and E.M.C. Etter, Questionnaire-based assessment of wild boar/domestic pig interactions and implications for disease risk management in Corsica. Frontiers in Veterinary Science, 2017. 4(December): p. 198.

63. Trabucco, B., F. Chabrier, F. Jori, O. Maestrini, D. Cornélis, E. Etter, S. Molia, A. Relun, and F. Casabianca, Stakeholder's practices and representations of contacts between domestic and wild pigs: a new approach for disease risk assessment? Acta argiculturae Slovenica, 2013: p. 117-122. 
626 64. Benham, P.F.J. and D.M. Broom, Interactions between cattle and badgers at 627 pasture with reference to bovine tuberculosis transmission. British Veterinary 628 Journal, 1989. 145(3): p. 226-341.

629 65. Drewe, J.A., N. Weber, S.P. Carter, S. Bearhop, X.A. Harrison, S.R.X. Dall, R.A. 630 McDonald, and R.J. Delahay, Performance of proximity loggers in recording 631

632

633

634

635

636

637 intra- and inter-species interactions: A laboratory and field-based validation study. PLoS ONE, 2012. 7(6): p. - .

66. Garnett, B.T., R.J. Delahay, and T.J. Roper, Use of cattle farm resources by badgers (Meles meles) and risk of bovine tuberculosis (Mycobacterium bovis) transmission to cattle. Proceedings of the Royal Society of London. Series B, Biological Sciences, 2002. 269(1499): p. 1487-1491.

67. Woodroffe, R., C.A. Donnelly, C. Ham, S.Y.B. Jackson, K. Moyes, K. Chapman, N.G. Stratton, and S.J. Cartwright, Badgers prefer cattle pasture but avoid cattle: implications for bovine tuberculosis control. Ecology Letters, 2016. 19(10): p. 1201-1208.

68. Walter, W.D., C.W. Anderson, R. Smith, M. Vanderklok, J.J. Averill, and K.C. VerCauteren, On-farm mitigation of transmission of tuberculosis from white-tailed deer to cattle: literature review and recommendations. Veterinary Medicine International, 2012. 2012: p. Article ID 616318.

69. Hill, J.A., Wildlife-cattle interactions in northern Michigan: implications for the transmission of bovine tuberculosis. 2005.

70. Balseiro, A., Á. Oleaga, L.M.Á. Morales, P.G. Quirós, C. Gortázar, and J.M. Prieto, Effectiveness of a calf-selective feeder in preventing wild boar access. European Journal of Wildlife Research, 2019. 65(3): p. 38.

71. Barasona, J.A., J. Vicente, I. Díez-Delgado, J. Aznar, C. Gortázar, and M.J. Torres, Environmental presence of Mycobacterium tuberculosis complex in aggregation points at the wildlife/livestock interface. Transboundary and emerging diseases, 2017. 64(4): p. 1148-1158.

72. Cadenas-Fernández, E., J.M. Sanchez-Vizcaino, A. Pintore, D. Denurra, M. Cherchi, C. Jurado, J. Vicente, and J.A. Barasona, Free-ranging pig and wild boar interactions in an endemic area of African swine fever. Frontiers in veterinary science, 2019. 6: p. 376.

73. Payne, A., S. Chappa, J. Hars, B. Dufour, and E. Gilot-Fromont, Wildlife visits to farm facilities assessed by camera traps in a bovine tuberculosis-infected area in France. European Journal of Wildlife Research, 2016. 62(1): p. 33-42. 
661 74. Richomme, C., D. Gauthier, and E. Fromont, Contact rates and exposure to inter662 species disease transmission in mountain ungulates. Epidemiology and Infection, $6632006.134(1):$ p. 21-30.

664 75. Wu, N., C. Abril, A. Thomann, E. Grosclaude, M.G. Doherr, P. Boujon, and M.P. 665

79. Arzamendia, Y. and B. Vilá, Vicugna habitat use and interactions with domestic ungulates in Jujuy, Northwest Argentina. Mammalia, 2015. 79(3): p. 267-278.

80. Colman, J.E., D. Tsegaye, C. Pedersen, R. Eidesen, H. Arntsen, Ø. Holand, A. Mann, E. Reimers, and S.R. Moe, Behavioral interference between sympatric reindeer and domesticated sheep in Norway. Rangeland Ecology \&amp// Management, 2012. 65(3): p. 299-308.

81. Kolowski, J.M. and K.E. Holekamp, Spatial, temporal, and physical characteristics of livestock depredations by large carnivores along a Kenyan reserve border. Biological Conservation, 2006. 128(4): p. 529-541.

82. Laporte, I., T.B. Muhly, J.A. Pitt, M. Alexander, and M. Musiani, Effects of wolves on elk and cattle behaviors: implications for livestock production and wolf conservation. PLoS ONE, 2010(No.August): p. e11954.

83. Mattiello, S., A. Pozzi, P. Leggeri, M. Trabalza-Marinucci, W. Redaelli, and C. Carenzi, Social and spatial interactions between red deer and cattle in the Italian alps. Zeitschrift fur Saugetierkunde, 1997. 62(SUPPL. 2): p. 134-138.

84. Steyaert, S.M., O.-G. Støen, M. Elfström, J. Karlsson, R. Van Lammeren, J. Bokdam, A. Zedrosser, S. Brunberg, and J.E. Swenson, Resource selection by 
697

698

699

700

701

702

703

704

705

706

707

708

709

710

711

712

713

714

715

716

717

718

719

720

721

722

723

724

725

726

727

728

729

730

731

732

733 sympatric free-ranging dairy cattle and brown bears Ursus arctos. Wildlife biology, 2011. 17(4): p. 389-403.

85. Rüttimann, S., M. Giacometti, and A.G. McElligott, Effect of domestic sheep on chamois activity, distribution and abundance on sub-alpine pastures. European Journal of Wildlife Research, 2008. 54(1): p. 110-116.

86. Schroeder, N.M., R. Ovejero, P.G. Moreno, P. Gregorio, P. Taraborelli, S.D. Matteucci, and P.D. Carmanchahi, Including species interactions in resource selection of guanacos and livestock in Northern Patagonia. Journal of Zoology, 2013. 291(3): p. 213-225.

87. Stahl, P., J.M. Vandel, S. Ruette, L. Coat, Y. Coat, and L. Balestra, Factors affecting lynx predation on sheep in the French Jura. Journal of Applied Ecology, 2002. 39(2): p. 204-216.

88. Anderson, A., C. Slootmaker, E. Harper, R.S. Miller, and S.A. Shwiff, Predation and disease-related economic impacts of wild pigs on livestock producers in 13 states. Crop protection, 2019. 121: p. 121-126.

89. Barasona, J.A., K.C. VerCauteren, N. Saklou, C. Gortazar, and J. Vicente, Effectiveness of cattle operated bump gates and exclusion fences in preventing ungulate multi-host sanitary interaction. Preventive Veterinary Medicine, 2013. 111(01-Feb): p. 42-50.

90. Carrasco-Garcia, R., J.A. Barasona, C. Gortazar, V. Montoro, J.M. SanchezVizcaino, and J. Vicente, Wildlife and livestock use of extensive farm resources in South Central Spain: implications for disease transmission. European Journal of Wildlife Research, 2016. 62(1): p. 65-78.

91. Carusi, L.C.P., M.S. Beade, and D.N. Bilenca, Spatial segregation among pampas deer and exotic ungulates: A comparative analysis at site and landscape scales. Journal of Mammalogy, 2017. 98(3): p. 761-769.

92. Howe, R., R. Boone, J. DeMartini, T. McCabe, and M. Coughenour, A spatially integrated disease risk assessment model for wildlife/livestock interactions in the Ngorongoro Conservation Area of Tanzania. Proceedings of the 9th Symposium of the International Society for Veterinary Epidemiology and Economics, Breckenridge, Colorado, USA, August 6-11 2000, 2000: p. Id 127.

93. Meunier, N.V., P. Sebulime, R.G. White, and R. Kock, Wildlife-livestock interactions and risk areas for cross-species spread of bovine tuberculosis. Onderstepoort Journal of Veterinary Research, 2017. 84(1): p. a1221.

94. Ward, A.I., B.A. Tolhurst, N.J. Walker, T.J. Roper, and R.J. Delahay, Survey of badger access to farm buildings and facilities in relation to contact with cattle. Veterinary Record, 2008. 163(4): p. 107-111. 
734 95. Weise, F.J., H. Hauptmeier, K.J. Stratford, M.W. Hayward, K. Aal, M. Heuer, M.

735

736

737

738

739

740

741

742

743

744

745

746

747

748

749

750

751

752

753

754

755

756

757

758

759

760

761

762

763

764

765

766

767

768

769
Tomeletso, V. Wulf, M.J. Somers, and A.B. Stein, Lions at the gates: Transdisciplinary design of an early warning system to improve human-lion coexistence. Frontiers in Ecology and Evolution, 2019. 6: p. 242.

96. Zarco-González, M. and O. Monroy-Vilchis, Effectiveness of low-cost deterrents in decreasing livestock predation by felids: a case in $C$ entral M exico. Animal Conservation, 2014. 17(4): p. 371-378.

97. Kaczensky, P., S. Khaliun, J. Payne, B. Boldgiv, B. Buuveibaatar, and C. Walzer, Through the eye of a Gobi khulan-Application of camera collars for ecological research of far-ranging species in remote and highly variable ecosystems. PloS one, 2019. 14(6).

98. Scantlebury, M., M.R. Hutchings, D.J. Allcroft, and S. Harris, Risk of disease from wildlife reservoirs: badgers, cattle, and bovine tuberculosis. Journal of Dairy Science, 2004. 87(2): p. 330-339.

99. Smith, L.A., G. Marion, D.L. Swain, P.C.L. White, and M.R. Hutchings, Interand intra-specific exposure to parasites and pathogens via the faecal-oral route: A consequence of behaviour in a patchy environment. Epidemiology and Infection, 2009. 137(5): p. 630-643.

100. Hutchings, M.R. and S. Harris, Quantifying the risks of TB infection to cattle posed by badger excreta. Epidemiology and Infection, 1999. 122(1): p. 167-174.

101. Brook, R.K., Incorporating farmer observations in efforts to manage bovine tuberculosis using barrier fencing at the wildlife-livestock interface. Preventive Veterinary Medicine, 2010.94(03-Apr): p. 301-305.

102. O'Mahony, D.T., Use of water troughs by badgers and cattle. Veterinary Journal, 2014. 202(3): p. 628-629.

103. Atwood, T.C., T.J. Deliberto, H.J. Smith, J.S. Stevenson, and K.C. Vercauteren, Spatial ecology of raccoons related to cattle and bovine tuberculosis in Northeastern Michigan. Journal of Wildlife Management, 2009. 73(5): p. 647-654.

104. Tsukada, H., M. Takeuchi, M. Fukasawa, and N. Shimizu, Depredation of concentrated feed by wild mammals at a stock farm in Japan. Mammal Study, 2010. 35(4): p. 281-287.

105. Barth, S.A., S. Blome, D. Cornelis, J. Pietschmann, M. Laval, O. Maestrini, L. Geue, F. Charrier, E. Etter, C. Menge, M. Beer, and F. Jori, Faecal Escherichia coli as biological indicator of spatial interaction between domestic pigs and wild boar (Sus scrofa) in Corsica. Transboundary and Emerging Diseases, 2018. 65(3): p. $746-757$. 
770 106. Maleko, D.D., G.N. Mbassa, W.F. Maanga, and E.S. Sisya, Impacts of wildlife-

771

772

773

774

775

776

777

778

779

780

781

782

783

784

785

786

787

788

789

790

791

792

793

794

795

796

797

798

799

800

801

802

803

804

805 livestock interactions in and around Arusha National Park, Tanzania. Current Research Journal of Biological Sciences, 2012. 4(4): p. 471-476.

107. Mullen, E.M., T. MacWhite, P.K. Maher, D.J. Kelly, N.M. Marples, and M. Good, Foraging Eurasian badgers Meles meles and the presence of cattle in pastures. Do badgers avoid cattle? Applied Animal Behaviour Science, 2013. 144(03-Apr): p. 130-137.

108. Ribeiro-Lima, J., M. Carstensen, L. Cornicelli, J.D. Forester, and S.J. Wells, Patterns of cattle farm visitation by white-tailed deer in relation to risk of disease transmission in a previously infected area with bovine tuberculosis in Minnesota, USA. Transboundary and Emerging Diseases, 2017. 64(5): p. 1519-1529.

109. Robertson, A., R.J. Delahay, G.J. Wilson, I.J. Vernon, R.A. McDonald, and J. Judge, How well do farmers know their badgers? Relating farmer knowledge to ecological survey data. Veterinary Record, 2017. 180(2): p. 48.

110. Woodroffe, R., C.A. Donnelly, C. Ham, S.Y.B. Jackson, K. Moyes, K. Chapman, N.G. Stratton, and S.J. Cartwright, Use of farm buildings by wild badgers: implications for the transmission of bovine tuberculosis. European Journal of Wildlife Research, 2017. 63(1): p. 6.

111. Triguero-Ocaña, R., J.A. Barasona, F. Carro, R.C. Soriguer, J. Vicente, and P. Acevedo, Spatio-temporal trends in the frequency of interspecific interactions between domestic and wild ungulates from Mediterranean Spain. PloS one, 2019. 14(1).

112. Bromen, N.A., J.T. French, J. Walker, and J.M. Tomeček, Spatial relationships between livestock guardian dogs and mesocarnivores in central Texas. HumanWildlife Interactions, 2019. 13(1): p. 8.

113. Chavez, A.S. and E.M. Gese, Landscape use and movements of wolves in relation to livestock in a wildland-agriculture matrix. Journal of Wildlife Management, 2006. 70(4): p. 1079-1086.

114. Ham, C., C.A. Donnelly, K.L. Astley, S.Y. Jackson, and R. Woodroffe, Effect of culling on individual badger Meles meles behaviour: Potential implications for bovine tuberculosis transmission. Journal of Applied Ecology, 2019. 56(11): p. 2390-2399.

115. Muhly, T.B., M. Alexander, M.S. Boyce, R. Creasey, M. Hebblewhite, D. Paton, J.A. Pitt, and M. Musiani, Differential risk effects of wolves on wild versus domestic prey have consequences for conservation. Oikos, 2010. 119(8): p. 12431254. 
806 116. Odadi, W.O., D.M. Kimuyu, R.L. Sensenig, K.E. Veblen, C. Riginos, and T.P.

807

808

809

810

811

812

813

814

815

816

817

818

819

820

821

822

823

824

825

826

827

828

829

830

831

832

833

834

835

836

837

838

839

840

841

842 Young, Fire-induced negative nutritional outcomes for cattle when sharing habitat with native ungulates in an African savanna. Journal of Applied Ecology, 2017. 54(3): p. 935-944.

117. Gehring, T.M., K.C. VerCauteren, M.L. Provost, and A.C. Cellar, Utility of livestock-protection dogs for deterring wildlife from cattle farms. Wildlife Research, 2010. 37(8): p. 715-721.

118. Braz, P.H., M.R. Oliveira, V.S. Silva, W.M. Tomas, R.S. Juliano, T.A. Moreira, N.P. Zimmermann, and A.O. Pellegrin, Risk of exposure of farms and subsistence nurseries to contact with wild boar in southern Mato Grosso do Sul. Pesquisa Veterinária Brasileira, 2019. 39(2): p. 148-154.

119. Judge, J., R.A. McDonald, N. Walker, and R.J. Delahay, Effectiveness of biosecurity measures in preventing badger visits to farm buildings. PLoS ONE, 2011(No.December): p. e28941.

120. Kamler, J.F., U. Stenkewitz, T. Gharajehdaghipour, and D.W. Macdonald, Social organization, home ranges, and extraterritorial forays of black-backed jackals. The Journal of Wildlife Management, 2019. 83(8): p. 1800-1808.

121. Van Der Weyde, L.K., T.Y. Hubel, J. Horgan, J. Shotton, R. McKenna, and A.M. Wilson, Movement patterns of cheetahs (Acinonyx jubatus) in farmlands in Botswana. Biology Open, 2017. 6(1): p. 118-124.

122. Viggers, K.L. and J.P. Hearn, The kangaroo conundrum: home range studies and implications for land management. Journal of Applied Ecology, 2005. 42(1): p. 99-107.

123. Berentsen, A.R., R.S. Miller, R. Misiewicz, J.L. Malmberg, and M.R. Dunbar, Characteristics of white-tailed deer visits to cattle farms: implications for disease transmission at the wildlife-livestock interface. European Journal of Wildlife Research, 2014. 60(2): p. 161-170.

124. Tolhurst, B.A., A.I. Ward, R.J. Delahay, A.M. MacMaster, and T.J. Roper, The behavioural responses of badgers (Meles meles) to exclusion from farm buildings using an electric fence. Applied Animal Behaviour Science, 2008. 113(01-Mar): p. 224-235.

125. Miguel, E., V. Grosbois, A. Caron, T. Boulinier, H. Fritz, D. Cornélis, C. Foggin, P.V. Makaya, P.T. Tshabalala, and M.d. Garine-Wichatitsky, Contacts and foot and mouth disease transmission from wild to domestic bovines in Africa. Ecosphere, 2013. 4(4): p. art51.

126. Miguel, E., V. Grosbois, H. Fritz, A. Caron, M.d. Garine-Wichatitsky, F. Nicod, A.J. Loveridge, B. Stapelkamp, D.W. Macdonald, and M. Valeix, Drivers of foot- 
843

844

845

846

847

848

849

850

851

852

853

854

855

856

857

858

859

860

861

862

863

864

865

866

867

868

869

870

871

872

873

874

875

876

877

and-mouth disease in cattle at wild/domestic interface: insights from farmers, buffalo and lions. Diversity and Distributions, 2017. 23(9): p. 1018-1030.

127. Abade, L., J. Cusack, R.J. Moll, P. Strampelli, A.J. Dickman, D.W. Macdonald, and R.A. Montgomery, Spatial variation in leopard (Panthera pardus) site use across a gradient of anthropogenic pressure in Tanzania's Ruaha landscape. PloS one, 2018. 13(10).

128. Acebes, P., J. Traba, and J.E. Malo, Co-occurrence and potential for competition between wild and domestic large herbivores in a South American desert. Journal of Arid Environments, 2012. 77: p. 39-44.

129. Atickem, A. and L.E. Loe, Livestock-wildlife conflicts in the Ethiopian highlands: assessing the dietary and spatial overlap between mountain nyala and cattle. African Journal of Ecology, 2014. 52(3): p. 343-351.

130. Borgnia, M., B.L. Vilá, and M.H. Cassini, Interaction between wild camelids and livestock in an Andean semi-desert. Journal of Arid Environments, 2008. 72(12): p. 2150-2158.

131. Coe, P.K., B.K. Johnson, J.W. Kern, S.L. Findholt, J.G. Kie, and M.J. Wisdom, Responses of elk and mule deer to cattle in summer. Journal of Range Management, 2001. 54(2 (Special Electronic Section)): p. A51-A76.

132. Cohen, W.E., D.L. Drawe, F.C. Bryant, and L.C. Bradley, Observations on whitetailed deer and habitat response to livestock grazing in south Texas. Journal of Range Management, 1989. 42(5): p. 361-365.

133. Dohna, H.z., D.E. Peck, B.K. Johnson, A. Reeves, and B.A. Schumaker, Wildlifelivestock interactions in a western rangeland setting: quantifying disease-relevant contacts. Preventive Veterinary Medicine, 2014. 113(4): p. 447-456.

134. Engeman, R., C. Betsill, and T. Ray, Making contact: rooting out the potential for exposure of commercial production swine facilities to feral swine in North Carolina. EcoHealth, 2011. 8(1): p. 76-81.

135. Jori, F., W. Vosloo, B.d. Plessis, R. Bengis, D. Brahmbhatt, B. Gummow, and G.R. Thomson, A qualitative risk assessment of factors contributing to foot and mouth disease outbreaks in cattle along the western boundary of the Kruger National Park. Revue Scientifique et Technique - Office International des Épizooties, 2009. 28(3): p. 917-931.

136. Kitts-Morgan, S.E., R.E. Carleton, S.L. Barrow, K.A. Hilburn, and A.K. Kyle, Wildlife visitation on a multi-unit educational livestock facility in northwestern Georgia. Southeastern Naturalist, 2015. 14(2): p. 267-280. 
878 137. Knust, B.M., P.C. Wolf, and S.J. Wells, Characterization of the risk of deer-cattle

879

880

881

882

883

884

885

886

887

888

889

890

891

892

893

894

895

896

897

898

899

900

901

902

903

904

905

906

907

908

909

910

911 interactions in Minnesota by use of an on-farm environmental assessment tool. American journal of veterinary research, 2011. 72(7): p. 924-931.

138. Kuiters, A.T., G.W.T.A.G. Bruinderink, and D.R. Lammertsma, Facilitative and competitive interactions between sympatric cattle, red deer and wild boar in Dutch woodland pastures. Acta Theriologica, 2005. 50(2): p. 241-252.

139. Loft, E.R., J.W. Menke, and J.G. Kie, Interaction of cattle and deer on mountain rangeland. California Agriculture, 1986. 40(01-Feb): p. 06-Sep.

140. Moa, P.F., I. Herfindal, J.D. Linnell, K. Overskaug, T. Kvam, and R. Andersen, Does the spatiotemporal distribution of livestock influence forage patch selection in Eurasian lynx Lynx lynx? Wildlife Biology, 2006. 12(1): p. 63-70.

141. Pearson, H.E., J.A.L.M.L. Toribio, M. Hernandez-Jover, D. Marshall, and S.J. Lapidge, Pathogen presence in feral pigs and their movement around two commercial piggeries in Queensland, Australia. Veterinary Record, 2014. 174(13): p. 325.

142. Salter, R.E. and R.J. Hudson, Range relationship of feral horses with wild ungulates and cattle in western Alberta. Journal of Range Management, 1980. 33(4): p. 266-271.

143. Shrestha, R., Coexistence of wild and domestic ungulates in the Nepalese TransHimalaya: resource competition or habitat partitioning?, in Coexistence of wild and domestic ungulates in the Nepalese Trans-Himalaya: resource competition or habitat partitioning? 2007:_s, Norway. p. 35 pp.

144. Valls-Fox, H., S. Chamaillé-Jammes, M. de Garine-Wichatitsky, A. Perrotton, N. Courbin, E. Miguel, C. Guerbois, A. Caron, A. Loveridge, B. Stapelkamp, M. Muzamba, and H. Fritz, Water and cattle shape habitat selection by wild herbivores at the edge of a protected area. Animal Conservation, 2018: p. - .

145. Wronski, T., J.D. Bariyanga, A. Apio, and M. Plath, Interactions between wildlife, humans and cattle: activity patterns of a remnant population of impala on the degraded Mutara Rangelands, Rwanda. Rangeland Journal, 2015. 37(4): p. 357365.

146. Anon, Caught on camera: surveillance monitors badgers' visits to farms. The Veterinary record, 2013. 173(5): p. 105-. 


\section{Figure 1}

Flow chart documenting literature retrieval and criteria used to select articles for inclusion in the systematic review of direct and indirect contacts between wildlife and livestock.

Search categories (contact term, livestock and wildlife) were combined by the Boolean operator 'AND' to identify publications containing all three terms. Databases were searched up to 11 November 2019 with no historic limit.

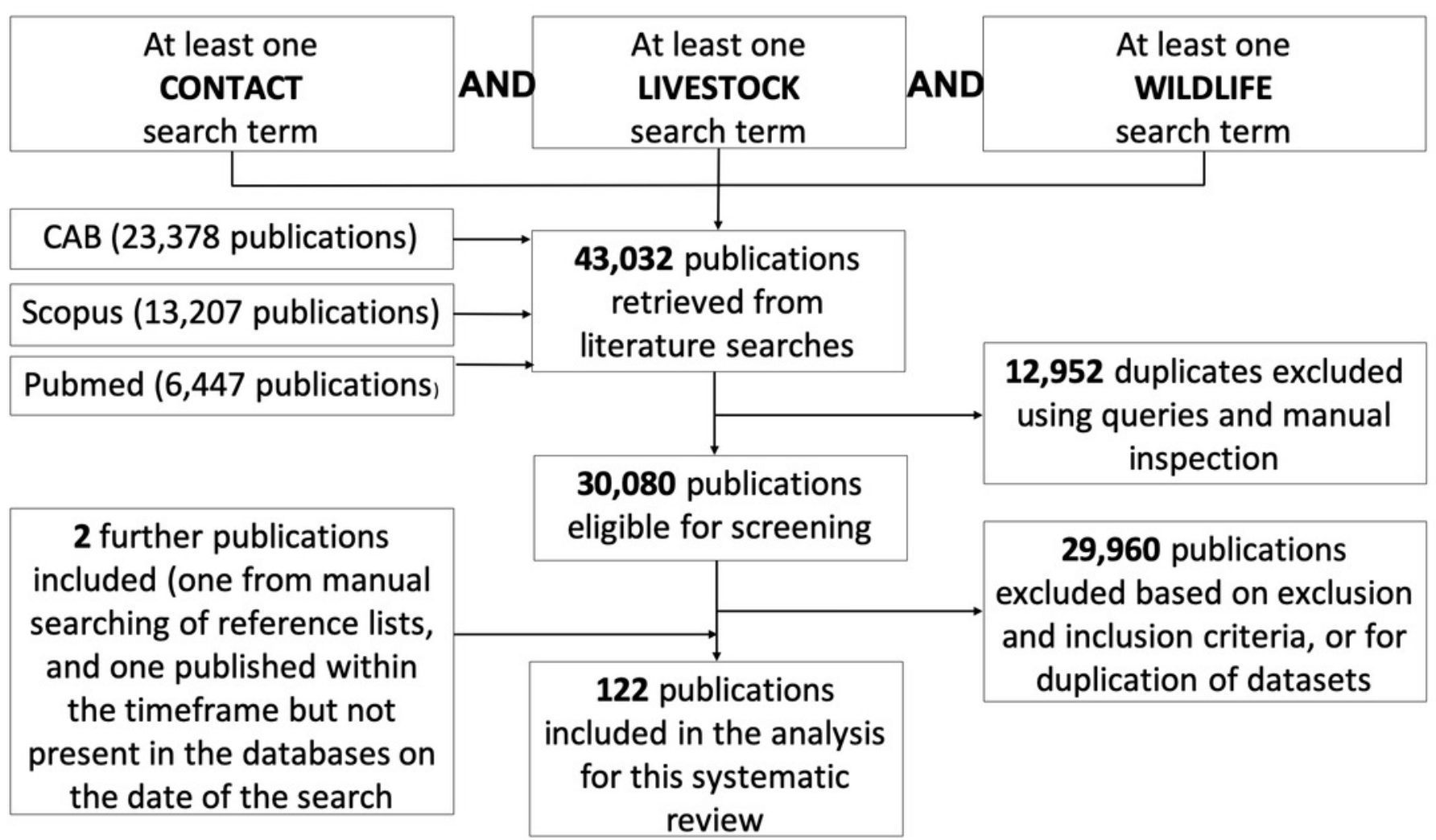




\section{Figure 2}

Distribution of the publication year of 122 publications included in the systematic review.

Publication date ranged from 1980 to 2019, with 117 (96\%) published in the last 20 years.

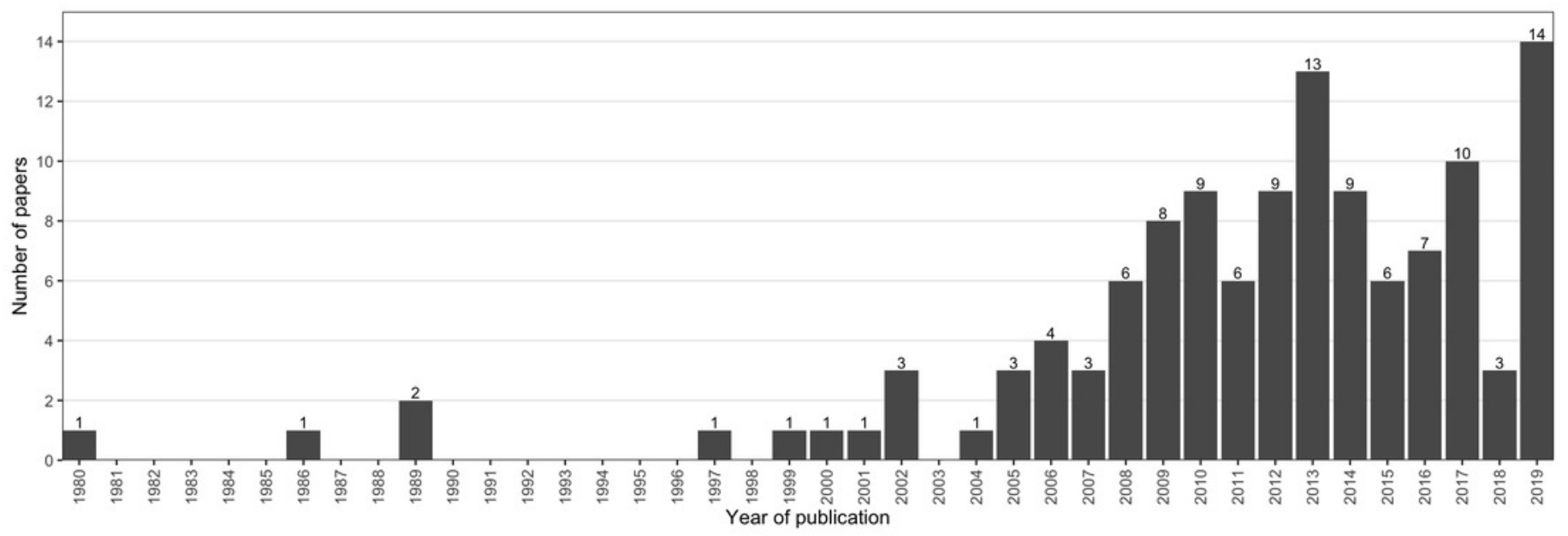




\section{Figure 3}

Observation methods used to monitor wildlife.

Data from 122 publications included in the systematic review. The size and shade of circles indicate the number of studies in each category. Many publications used more than one method to monitor contacts, and therefore the number of studies exceeds $122(100 \%)$ for some groups. 


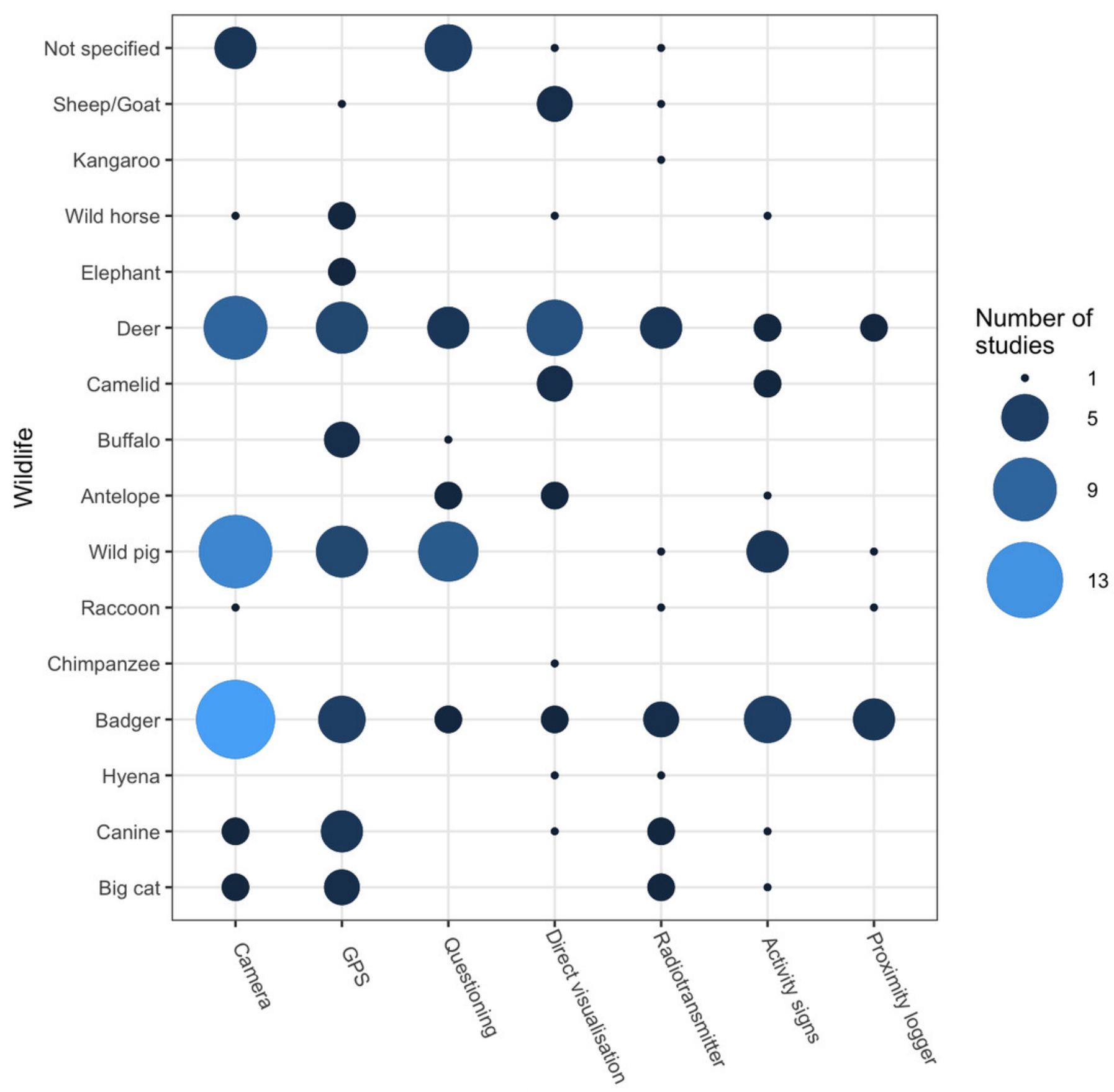

Methods 


\section{Figure 4}

A proposed generic framework for describing and categorising contacts between livestock and wildlife.

Examples from studies of contacts between badgers and cattle are provided to demonstrate the use of the framework. $S_{\mathrm{c} 1}$ represents 'critical space 1 ', the maximum amount of space (distance or area) within which direct contact may occur; and $\mathrm{T}_{\mathrm{C} 1}$ represents 'critical time 1', the maximum duration of time within which direct contact may occur. Similarly, $\mathrm{S}_{\mathrm{c2}}$ represents 'critical space 2', the maximum amount of space (distance or area) within which indirect contact may occur; and $\mathrm{T}_{\mathrm{C} 2}$ represents 'critical time 2 ', the maximum duration of time within which indirect contact may occur. Same, near and different are used here to illustrate spatial and temporal differences between examples (see Tables 3 and 4 for values and ranges for these parameters from published studies). Note that the lighter blue shading does not extend all the way to the right of the diagram because there is an upper limit to the value of time which $\mathrm{T}_{\mathrm{C} 2}$ can take: beyond this value, animals in the same (or nearby) space will not be in contact. 


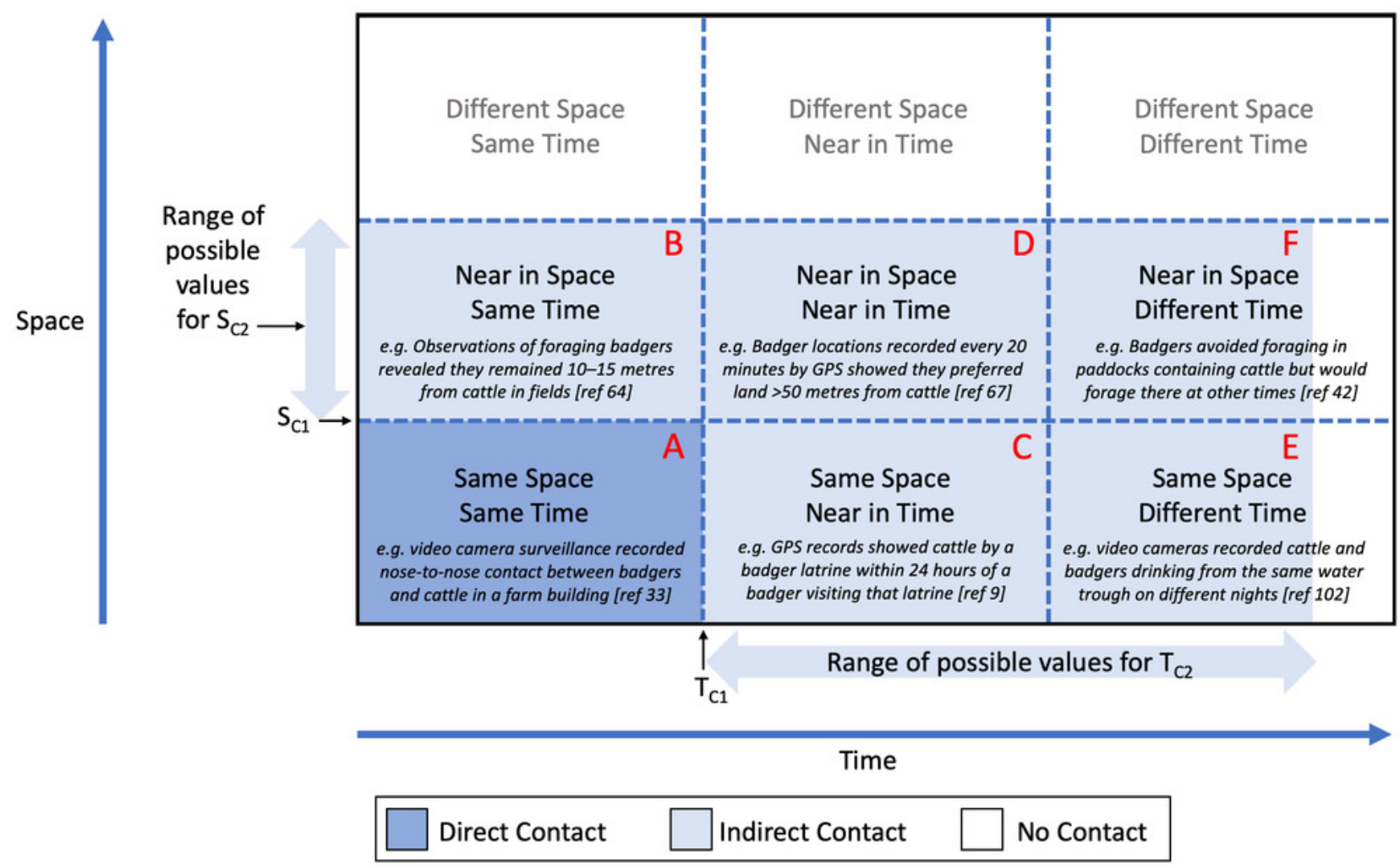




\section{Table $\mathbf{1}$ (on next page)}

Exclusion and inclusion criteria to select studies for the systematic review of livestockwildlife contact. 
1. Study does not involve a wild mammal species where adults are typically heavier than $5 \mathrm{~kg}$.

2. Study does not involve a farmed mammal species where adults are typically heavier than $5 \mathrm{~kg}$, or farmland associated with such livestock.

3. Study does not attempt to collect, use or analyse data to investigate contacts between wild animals and livestock or livestock farms.

4. Study does not attempt to collect, use or analyse data to establish at least one of the following: characterisation of, the nature of, frequency of, or risk factors for, contacts between wildlife and livestock.

5. Full text not available in English.

6. Full text not accessible to reviewers.

7. The method of recording livestock-wildlife contacts relies solely on predation events where the only observations are livestock kills or scat analysis

8. Wild animals were non-free-living, pre-tamed or relocated for the purpose of the study.

The study aims to collect, use, or analyse data to establish at least one of the following:

1. A quantifiable measure of direct contact between wildlife and livestock, where direct contact is defined as physical contact between at least one wild animal and one farm animal .

2. A quantifiable measure of indirect contact between wildlife and livestock, where indirect contact is defined as contact between at least one wild animal and a resource used by at least one farm animal including, but not limited to, food, water and space

3. Characterise and establish the type of, or risk factors for, direct or indirect contact between wildlife and livestock, as defined above. 


\section{Table 2 (on next page)}

Definitions of direct contact from a systematic review of studies of livestock and wildlife.

Parameters are listed in ascending order of distance and time between animals and time windows. Definitions that have been used for both direct and indirect contacts are shaded grey. Percentages are rounded to the nearest integer. 
1

\begin{tabular}{|c|c|c|c|}
\hline 'Direct contact' definition & $\begin{array}{l}\text { Number }(\%) \text { of } \\
\text { publications using this } \\
\text { definition }\end{array}$ & $\%$ Cumulative & References \\
\hline $\begin{array}{l}\text { At least two individuals } \\
\text { making physical contact }\end{array}$ & $9(16)$ & 16 & {$[33,56-63]$} \\
\hline $\begin{array}{l}\text { Individuals close enough to } \\
\text { inhale expired breath }\end{array}$ & $1(2)$ & 18 & [64] \\
\hline $\begin{array}{l}\text { Individuals within one } \\
\text { metre of the same location } \\
\text { within one second }\end{array}$ & $1(2)$ & 20 & {$[15]$} \\
\hline $\begin{array}{l}\text { Individuals within two } \\
\text { metres of each other }\end{array}$ & $5(9)$ & 29 & $\begin{array}{l}{[9,40,65-} \\
67]\end{array}$ \\
\hline $\begin{array}{l}\text { Individuals within five } \\
\text { metres of each other }\end{array}$ & $3(5)$ & 34 & {$[8,68,69]$} \\
\hline $\begin{array}{l}\text { Individuals within the same } \\
\text { camera image }\end{array}$ & $5(9)$ & 43 & {$[35,70-73]$} \\
\hline $\begin{array}{l}\text { Individuals within } 20 \text { metres } \\
\text { of each other }\end{array}$ & $1(2)$ & 45 & [74] \\
\hline $\begin{array}{l}\text { Individuals within } 20 \text { metres } \\
\text { of the same location within } \\
15 \text { minutes }\end{array}$ & $1(2)$ & 46 & [39] \\
\hline $\begin{array}{l}\text { Individuals within same } \\
\text { farm building }\end{array}$ & $1(2)$ & 48 & {$[34]$} \\
\hline $\begin{array}{l}\text { Individuals within holding } \\
\text { (farm) boundary }\end{array}$ & $1(2)$ & 50 & [75] \\
\hline $\begin{array}{l}\text { Individuals within } 100 \\
\text { metres of each other }\end{array}$ & $2(4)$ & 54 & {$[76,77]$} \\
\hline $\begin{array}{l}\text { Individuals within } 120 \\
\text { metres of each other }\end{array}$ & $1(2)$ & 55 & {$[78]$} \\
\hline $\begin{array}{l}\text { Studies that reported the } \\
\text { frequency of, types of, or } \\
\text { risk factors for, direct } \\
\text { contacts without first } \\
\text { defining them }\end{array}$ & $25(45)$ & 100 & $\begin{array}{l}{[13,22,25,} \\
26,29,30 \\
41,79-96]\end{array}$ \\
\hline Total & $56(100)$ & & \\
\hline
\end{tabular}

2 


\section{Table 3 (on next page)}

Definitions of indirect contact from a systematic review of studies of livestock and wildlife.

Parameters are listed in ascending order of distance and time. Definitions that have been used for both direct and indirect contacts are shaded grey. Percentages are rounded to the nearest integer. 
1

\begin{tabular}{|c|c|c|c|}
\hline 'Indirect contact' definition & $\begin{array}{l}\text { Number }(\%) \text { of } \\
\text { publications } \\
\text { using this } \\
\text { definition }\end{array}$ & $\%$ Cumulative & References \\
\hline $\begin{array}{l}\text { Individuals within the same camera } \\
\text { image }\end{array}$ & $2(2)$ & 2 & {$[73,97]$} \\
\hline $\begin{array}{l}\text { Two individuals photographed by the } \\
\text { same camera trap within a specific time } \\
\text { interval }\end{array}$ & $1(1)$ & 3 & [35] \\
\hline Latrine (faecal pits) visits & $5(4)$ & 7 & $\begin{array}{l}{[9,65,98-} \\
100]\end{array}$ \\
\hline $\begin{array}{l}\text { Individuals visiting the same food or } \\
\text { water source at the same time }\end{array}$ & $2(2)$ & 9 & {$[25,62]$} \\
\hline $\begin{array}{l}\text { Individuals visiting the same food and } \\
\text { water sources at unspecified time } \\
\text { intervals }\end{array}$ & $13(11)$ & 20 & $\begin{array}{l}{[15,27,56} \\
63,66,68 \\
70,89,90 \\
101-104]\end{array}$ \\
\hline $\begin{array}{l}\text { Individuals in the same space at the same } \\
\text { time }\end{array}$ & $2(2)$ & 22 & {$[106,107]$} \\
\hline $\begin{array}{l}\text { Individuals in the same space at different } \\
\text { times }\end{array}$ & $3(3)$ & 24 & {$[31,58,105]$} \\
\hline $\begin{array}{l}\text { Individuals in the same space at } \\
\text { unspecified time interval }\end{array}$ & $3(3)$ & 27 & {$[10,12,69]$} \\
\hline $\begin{array}{l}\text { Individuals using the same food or water } \\
\text { source within six hours }\end{array}$ & $1(1)$ & 28 & [40] \\
\hline $\begin{array}{l}\text { Individuals within } 20 \text { metres of the same } \\
\text { location within six hours }\end{array}$ & $1(1)$ & 28 & [39] \\
\hline $\begin{array}{l}\text { Individuals within } 30 \text { metres of livestock } \\
\text { or feed }\end{array}$ & $1(1)$ & 29 & {$[108]$} \\
\hline $\begin{array}{l}\text { Presence in farm buildings at unspecified } \\
\text { time interval }\end{array}$ & $5(4)$ & 34 & $\begin{array}{l}{[26,33,59} \\
109,110]\end{array}$ \\
\hline $\begin{array}{l}\text { Individuals within } 50 \text { metres of each } \\
\text { other }\end{array}$ & $1(1)$ & 34 & [85] \\
\hline $\begin{array}{l}\text { Individuals within } 52 \text { metres of the same } \\
\text { location within one hour }\end{array}$ & $1(1)$ & 35 & {$[111]$} \\
\hline Individuals within 120 metres & $1(1)$ & 36 & [28] \\
\hline $\begin{array}{l}\text { Individuals using the same space with } \\
\text { seven days }\end{array}$ & $2(2)$ & 38 & {$[24,72]$} \\
\hline Individuals using the same space within & $1(1)$ & 39 & [74] \\
\hline
\end{tabular}




\begin{tabular}{|c|c|c|c|}
\hline 'Indirect contact' definition & $\begin{array}{l}\text { Number }(\%) \text { of } \\
\text { publications } \\
\text { using this } \\
\text { definition }\end{array}$ & $\%$ Cumulative & References \\
\hline \multicolumn{4}{|l|}{15 days } \\
\hline Presence on pasture at the same time & $5(4)$ & 43 & $\begin{array}{l}{[49,64,91} \\
95,96]\end{array}$ \\
\hline $\begin{array}{l}\text { Presence on pasture at unspecified time } \\
\text { interval }\end{array}$ & $8(7)$ & 50 & $\begin{array}{l}{[30,34,36,} \\
67,112-115]\end{array}$ \\
\hline Presence on pasture at different times & $1(1)$ & 51 & {$[116]$} \\
\hline $\begin{array}{l}\text { At holding boundary and on pasture at } \\
\text { unspecified time interval }\end{array}$ & $1(1)$ & 52 & {$[117]$} \\
\hline $\begin{array}{l}\text { Presence on farm at unspecified time } \\
\text { interval }\end{array}$ & $12(10)$ & 62 & $\begin{array}{l}{[42,43,50} \\
54,88,94 \\
118-123]\end{array}$ \\
\hline At holding (farm) boundary & $3(3)$ & 65 & {$[60,61,124]$} \\
\hline $\begin{array}{l}\text { Individuals within } 120 \text { metres of the } \\
\text { same location at different times }\end{array}$ & $1(1)$ & 66 & {$[78]$} \\
\hline $\begin{array}{l}\text { Individuals within } 300 \text { metres of the } \\
\text { same location within } 15 \text { days }\end{array}$ & $2(2)$ & 67 & {$[125,126]$} \\
\hline $\begin{array}{l}\text { Individuals within } 500 \text { metres of the } \\
\text { same location within six weeks }\end{array}$ & $1(1)$ & 68 & {$[93]$} \\
\hline $\begin{array}{l}\text { Individuals within } 500 \text { metres from } \\
\text { holding (farm) boundary }\end{array}$ & $2(2)$ & 70 & {$[75,76]$} \\
\hline $\begin{array}{l}\text { Individuals within } 50 \text { kilometres of the } \\
\text { same location within three months }\end{array}$ & $1(1)$ & 71 & {$[51]$} \\
\hline $\begin{array}{l}\text { Studies that reported the frequency of, } \\
\text { types of, or risk factors for, indirect } \\
\text { contacts without first defining them }\end{array}$ & $34(29)$ & 100 & $\begin{array}{l}{[22,23,29,} \\
32,37,41, \\
79-84,89, \\
92,127-146]\end{array}$ \\
\hline Total & $116(100)$ & & \\
\hline
\end{tabular}




\section{Table 4 (on next page)}

A summary of the types of contact(s) reported between livestock and wildlife, and the method(s) used to observe contacts, from a systematic review of 122 studies. 


\begin{tabular}{|c|c|c|c|c|c|c|}
\hline \multirow[t]{2}{*}{ Livestock } & \multirow[t]{2}{*}{ Wildlife } & \multirow[t]{2}{*}{ Method(s) ${ }^{*}$} & \multicolumn{2}{|c|}{$\begin{array}{l}\text { Type of contact } \\
\text { recorded }\end{array}$} & \multirow[t]{2}{*}{$\begin{array}{l}\text { Examples of the types of contact(s) reported between each livestock and wildlife } \\
\text { species }\end{array}$} & \multirow[t]{2}{*}{ Referen } \\
\hline & & & Direct & Indirect & & \\
\hline \multirow[t]{3}{*}{ Camelid } & Antelope & Multiple $(\mathrm{d}, \mathrm{k}, \mathrm{q})$ & Yes & Yes & Shared space use & {$[51]$} \\
\hline & \multirow[t]{2}{*}{ Camelid } & Direct visualisation & Yes & Yes & Wild camelids grazing with domestic llamas & {$[79]$} \\
\hline & & Multiple $(a, d)$ & No & Yes & Shared forage & {$[130]$} \\
\hline \multirow[t]{18}{*}{ Cattle } & \multirow[t]{5}{*}{ Antelope } & Activity signs & No & Yes & Shared space use & {$[129]$} \\
\hline & & Direct visualisation & No & Yes & Unspecified contact & {$[145]$} \\
\hline & & Model $^{\#}$ & No & Yes & No contacts observed & {$[92]$} \\
\hline & & Multiple $(a, k, q)$ & Yes & Yes & Shared space use & {$[51]$} \\
\hline & & Questioning & Yes & Yes & Shared space use. Shared grazing and water source & [93] \\
\hline & \multirow[t]{13}{*}{ Badger } & Activity signs & No & Yes & Cattle investigating or grazing at badger latrines and setts on pasture & {$[98]$} \\
\hline & & Camera & Yes & Yes & $\begin{array}{l}\text { Badgers and cattle being within two metres of each other. Cattle investigating } \\
\text { badger setts and latrines. Badgers visiting farms, feed stores and cattle houses and } \\
\text { foraging on cattle pasture. Shared use of water and feed troughs }\end{array}$ & $\begin{array}{l}{[54,58,73} \\
102,104,1 \\
146]\end{array}$ \\
\hline & & Direct visualisation & Yes & Yes & Badgers foraging on cattle pasture & {$[64]$} \\
\hline & & GPS & No & Yes & $\begin{array}{l}\text { Badger visits to cattle farms. Badgers and cattle being present on pasture at the } \\
\text { same time, and at different times }\end{array}$ & {$[42,107,1$} \\
\hline & & Model & No & Yes & Cattle grazing at or investigating badger latrines & {$[99,100]$} \\
\hline & & Multiple $(a, c, m)$ & Yes & Yes & $\begin{array}{l}\text { Badgers and cattle being within two metres of each other. Badgers visiting feed } \\
\text { stores and shared use of feed and water troughs }\end{array}$ & {$[66]$} \\
\hline & & Multiple $(a, c, r)$ & No & Yes & Badgers in and around cattle buildings & {$[109]$} \\
\hline & & Multiple $(a, q)$ & No & Yes & Badgers visiting cattle housing, feed stores and feed and water troughs & {$[12]$} \\
\hline & & Multiple $(a, c)$ & No & Yes & Badgers visiting farmyards & [43] \\
\hline & & Multiple $(d, c, r)$ & No & Yes & Badgers visiting farm boundaries & {$[124]$} \\
\hline & & Multiple $(c, g)$ & Yes & Yes & $\begin{array}{l}\text { Nose to nose contact. Badgers visiting farmyards, farm buildings and feed stores } \\
\text { and eating cattle feed }\end{array}$ & [33] \\
\hline & & Multiple (c,q) & Yes & Yes & $\begin{array}{l}\text { Nose to nose contact. Badgers visiting, urinating and defecating in farmyards, farm } \\
\text { buildings and feed stores and eating cattle feed }\end{array}$ & {$[94]$} \\
\hline & & Multiple $(c, r)$ & Yes & Yes & Shared space use & [67] \\
\hline
\end{tabular}




\begin{tabular}{|c|c|c|c|c|c|c|}
\hline \multirow[t]{21}{*}{ Livestock } & \multirow[t]{4}{*}{ Wildlife } & \multirow[t]{2}{*}{ Method(s) ${ }^{*}$} & \multicolumn{2}{|c|}{$\begin{array}{l}\text { Type of contact } \\
\text { recorded }\end{array}$} & \multirow[t]{2}{*}{$\begin{array}{c}\text { Examples of the types of contact(s) reported between each livestock and wildlife } \\
\text { species }\end{array}$} & \multirow[t]{2}{*}{ Referen } \\
\hline & & & Direct & Indirect & & \\
\hline & & Multiple (c,I) & Yes & Yes & Shared use of feed troughs & [110] \\
\hline & & Proximity logger & Yes & Yes & $\begin{array}{l}\text { Badgers and cattle being within one to two metres of each other. Cattle visits to } \\
\text { badger latrines }\end{array}$ & {$[8,9,65]$} \\
\hline & \multirow[t]{3}{*}{ Big cat } & Camera & No & Yes & No contacts observed & {$[127]$} \\
\hline & & GPS & No & Yes & Lion presence on cattle pasture. Cheetah visits to cattle farms & {$[95,121]$} \\
\hline & & Multiple $(a, c)$ & Yes & Yes & Predation events and wild felid presence oncattle pasture & [96] \\
\hline & \multirow[t]{4}{*}{ Buffalo } & GPS & No & Yes & Shared space and water sources & $\begin{array}{l}{[125,126,} \\
144]\end{array}$ \\
\hline & & Model & Yes & No & Cattle and buffalo being within 100 metres of each other & [77] \\
\hline & & Literature review & No & Yes & $\begin{array}{l}\text { Young buffalo joining cattle herd and 'contact' (unspecified) between cattle and } \\
\text { buffalo }\end{array}$ & [135] \\
\hline & & Questioning & Yes & Yes & Shared grazing and water source & {$[93]$} \\
\hline & \multirow[t]{3}{*}{ Camelid } & Activity signs & No & Yes & No contacts observed & {$[128]$} \\
\hline & & Direct visualisation & Yes & No & No contacts observed & {$[79,86]$} \\
\hline & & Multiple $(a, d)$ & No & Yes & Shared forage & {$[130]$} \\
\hline & \multirow[t]{4}{*}{ Canine } & Camera & Yes & Yes & $\begin{array}{l}\text { Cattle and foxes being within two metres of each other. Foxes visiting farm } \\
\text { buildings, foraging and hunting on farmland and defecating on stored feed }\end{array}$ & [59] \\
\hline & & GPS & Yes & Yes & Wolf visits to cattle pasture & {$[82,84,11$} \\
\hline & & Multiple $(a, d)$ & No & Yes & Wolf and coyote presence on cattle pasture & {$[117]$} \\
\hline & & Radio-telemetry & No & Yes & Wolf visits to cattle pasture. Jackal visits to cattle farms & {$[113,120]$} \\
\hline & \multirow[t]{3}{*}{ Deer } & Activity signs & No & Yes & Deer presence on pasture previously grazed by cattle & {$[138]$} \\
\hline & & Camera & Yes & Yes & Shared use of feed and water troughs & $\begin{array}{l}{[35,73,89} \\
104]\end{array}$ \\
\hline & & Direct visualisation & Yes & Yes & $\begin{array}{l}\text { Aggression between deer and cattle, and deer and cattle being within five metres } \\
\text { of each other. Deer visits to cattle feed stores and deer presence on pasture at the } \\
\text { same time and at different times to cattle. Deer licking cattle urine }\end{array}$ & {$[41,69,83$} \\
\hline
\end{tabular}




\begin{tabular}{|c|c|c|c|c|c|c|}
\hline \multirow[t]{22}{*}{ Livestock } & \multirow[t]{12}{*}{ Wildlife } & \multirow[t]{2}{*}{ Method(s) ${ }^{*}$} & \multicolumn{2}{|c|}{$\begin{array}{l}\text { Type of contact } \\
\text { recorded }\end{array}$} & \multirow[t]{2}{*}{$\begin{array}{c}\text { Examples of the types of contact(s) reported between each livestock and wildlife } \\
\text { species }\end{array}$} & \multirow[t]{2}{*}{ Referen } \\
\hline & & & Direct & Indirect & & \\
\hline & & GPS & No & Yes & Deer visits to cattle pastures and feeding areas & {$[32,108,1$} \\
\hline & & Literature review & Yes & Yes & No contacts observed & [68] \\
\hline & & Multiple $(a, c)$ & Yes & Yes & Cattle and deer at water sources at the same time & [71] \\
\hline & & Multiple $(d, c)$ & Yes & Yes & Unspecified contact & [56] \\
\hline & & Multiple $(c, p)$ & Yes & Yes & $\begin{array}{l}\text { Cattle and deer within } 1.5 \text { metres of each other. Shared use of water and food } \\
\text { points }\end{array}$ & {$[40]$} \\
\hline & & Multiple (g,l) & No & Yes & Deer presence on cattle pasture & {$[117]$} \\
\hline & & Multiple (g,q) & Yes & Yes & Unspecified direct contact. Deer visits to cattle feed stores & {$[30,136]$} \\
\hline & & Proximity logger & Yes & Yes & Deer visits to stored feed & [15] \\
\hline & & Questioning & No & Yes & Deer presence on cattle farms, and visiting and damaging feed stores & {$[101,137]$} \\
\hline & & Radio-telemetry & No & Yes & Deer visits to cattle pasture and shared salt licks & {$[131-133$,} \\
\hline & Elephant & GPS & No & Yes & $\begin{array}{l}\text { Elephant home range overlapping with cattle grazing. Elephants using same water } \\
\text { source at the same time and at different times to cattle }\end{array}$ & {$[31,144]$} \\
\hline & Hyena & Multiple $(d, r)$ & Yes & Yes & Predation events & {$[81]$} \\
\hline & Kangaroo & Radio-telemetry & No & Yes & Kangaroo presence on cattle farms & {$[122]$} \\
\hline & Not specified & Camera & Yes & Yes & $\begin{array}{l}\text { Racoons licking salt lick less than thirty centimetres away from cattle, and sharing } \\
\text { water sources. Savannah wildlife grazing at the same and at different times to } \\
\text { cattle }\end{array}$ & {$[24,26,11$} \\
\hline & & Direct visualisation & Yes & Yes & $\begin{array}{l}\text { Cattle and savanna wildlife sharing water sources at the same and at different } \\
\text { times }\end{array}$ & {$[22]$} \\
\hline & & Questioning & Yes & Yes & $\begin{array}{l}\text { Wildlife and cattle sharing water sources and grazing at the same and at different } \\
\text { times }\end{array}$ & $\begin{array}{l}{[25,27-29} \\
106]\end{array}$ \\
\hline & & Radio-telemetry & No & Yes & No contacts observed & {$[23]$} \\
\hline & Raccoon & Multiple $(c, l, r)$ & No & Yes & Shared space use. Shared food and water sources & {$[103]$} \\
\hline & Sheep/Goat & Direct visualisation & Yes & Yes & Chamois and ibex in close proximity to cattle. Shared use of cattle pasture & [74] \\
\hline & & Multiple (g,m) & No & Yes & No contacts observed & [49] \\
\hline
\end{tabular}




\begin{tabular}{|c|c|c|c|c|c|c|}
\hline \multirow[t]{11}{*}{ Livestock } & \multirow[t]{2}{*}{ Wildlife } & \multirow[t]{2}{*}{ Method(s)* } & \multicolumn{2}{|c|}{$\begin{array}{l}\text { Type of contact } \\
\text { recorded }\end{array}$} & \multirow[t]{2}{*}{$\begin{array}{l}\text { Examples of the types of contact(s) reported between each livestock and wildlife } \\
\text { species }\end{array}$} & \multirow[t]{2}{*}{ Referenc } \\
\hline & & & Direct & Indirect & & \\
\hline & \multirow[t]{2}{*}{ Wild horse } & GPS & No & Yes & $\begin{array}{l}\text { Spatial overlap of zebra home ranges with cattle grazing areas. Shared use of water } \\
\text { source }\end{array}$ & {$[31]$} \\
\hline & & Multiple $(a, d)$ & No & Yes & Feral horses grazing in close proximity to cattle, and using pasture prior to cattle & {$[142]$} \\
\hline & \multirow[t]{7}{*}{ Wild pig } & Activity signs & No & Yes & Wild boar presence on pasture previously grazed by cattle & {$[36,138]$} \\
\hline & & Camera & Yes & Yes & $\begin{array}{l}\text { Wild boar and cattle sharing water sources and feed troughs at the same time and } \\
\text { at different times }\end{array}$ & $\begin{array}{l}{[35,70,73} \\
90,104]\end{array}$ \\
\hline & & GPS & No & Yes & Shared space and water sources & {$[10,111]$} \\
\hline & & Multiple (c,g) & Yes & Yes & Wild boar and cattle sharing water source at the same time & {$[71]$} \\
\hline & & Multiple $(c, p)$ & Yes & Yes & Feral pigs and cattle being within 20 metres of the same location at different times & [39] \\
\hline & & Multiple (g,l) & Yes & Yes & $\begin{array}{l}\text { Wild boar and cattle being within } 1.5 \text { metres of each other. Shared use of food and } \\
\text { water points }\end{array}$ & {$[40]$} \\
\hline & & Questioning & Yes & Yes & Shared water sources & {$[88,93]$} \\
\hline Farmed deer & Big cat & Radio-telemetry & No & Yes & No contacts observed & {$[140]$} \\
\hline \multirow[t]{12}{*}{ Goat } & Antelope & Multiple $(d, k, q)$ & Yes & Yes & Shared space use & {$[51]$} \\
\hline & \multirow[t]{2}{*}{ Big cat } & Camera & No & Yes & No contacts observed & {$[127]$} \\
\hline & & Multiple $(a, c)$ & Yes & Yes & Predation events and wild felid presence on goat pasture & {$[96]$} \\
\hline & \multirow[t]{2}{*}{ Camelid } & Direct visualisation & Yes & Yes & Shared forage sources at different times & {$[79,86]$} \\
\hline & & Multiple $(a, d)$ & No & Yes & Shared forage & {$[130]$} \\
\hline & Canine & Radio-telemetry & No & Yes & Jackal visits to goat farms & {$[120]$} \\
\hline & Chimpanzee & Direct visualisation & Yes & No & No contacts observed & {$[57]$} \\
\hline & Deer & Camera & Yes & Yes & No contacts observed & {$[90]$} \\
\hline & Hyena & Multiple $(d, r)$ & Yes & Yes & Predation events & {$[81]$} \\
\hline & Not specified & Camera & No & Yes & Presence on pasture of predators not associated with livestock predation & {$[112]$} \\
\hline & \multirow[t]{2}{*}{ Wild pig } & Camera & Yes & Yes & No contacts observed & {$[90]$} \\
\hline & & Questioning & Yes & Yes & Predation and presence on farm & {$[88]$} \\
\hline
\end{tabular}




\begin{tabular}{|c|c|c|c|c|c|c|}
\hline \multirow[t]{2}{*}{ Livestock } & \multirow[t]{2}{*}{ Wildlife } & \multirow[t]{2}{*}{ Method(s) ${ }^{*}$} & \multicolumn{2}{|c|}{$\begin{array}{l}\text { Type of contact } \\
\text { recorded }\end{array}$} & \multirow[t]{2}{*}{$\begin{array}{c}\text { Examples of the types of contact(s) reported between each livestock and wildlife } \\
\text { species }\end{array}$} & \multirow[t]{2}{*}{ Referen } \\
\hline & & & Direct & Indirect & & \\
\hline \multirow[t]{2}{*}{ Not specified } & Big cat & GPS & No & Yes & No contacts observed & [37] \\
\hline & Wild horse & Multiple $(c, g)$ & Yes & Yes & Livestock within photographing distance of khulan horses & [97] \\
\hline \multirow[t]{11}{*}{ Pig } & Canine & Camera & Yes & Yes & $\begin{array}{l}\text { Foxes approaching and entering farrowing huts and taking piglets. Fox presence in } \\
\text { pig paddocks }\end{array}$ & {$[34]$} \\
\hline & Deer & Multiple (g,l) & Yes & Yes & Deer and pigs within 1.5 metres of each other. Shared use of food and water & {$[40]$} \\
\hline & \multirow[t]{9}{*}{ Wild pig } & Camera & Yes & Yes & $\begin{array}{l}\text { Shared food and water sources. Wild boar visiting acorn fields used by domestic } \\
\text { pigs }\end{array}$ & {$[35,90]$} \\
\hline & & GPS & No & Yes & No contacts observed & {$[141]$} \\
\hline & & Multiple $(a, c, g)$ & No & Yes & Wild boar home range overlap with domestic pigs and shared space use & {$[105]$} \\
\hline & & Multiple $(a, c, q)$ & No & Yes & No contacts observed & {$[118]$} \\
\hline & & Multiple $(\mathrm{c}, \mathrm{m})$ & Yes & Yes & Pigs and wild boar present in the same camera trap image. Shared use of water & {$[72]$} \\
\hline & & Multiple $(c, q)$ & Yes & Yes & Wild boar and pigs within 1.5 metres of each other. Shared use of food and water & {$[40]$} \\
\hline & & Multiple $(m, q)$ & Yes & Yes & $\begin{array}{l}\text { Evidence of mating (cross-bred piglets). Wild boar within two metres of pig } \\
\text { enclosure }\end{array}$ & {$[75]$} \\
\hline & & Multiple $(p, r)$ & Yes & Yes & $\begin{array}{l}\text { Feral and domestic swine in contact through fences. Feral pigs within } 500 \text { metres } \\
\text { of pig farm }\end{array}$ & {$[76]$} \\
\hline & & Questioning & Yes & Yes & $\begin{array}{l}\text { Wild and domestic pigs fighting and mating. Shared use of water, food and space } \\
\text { at different times }\end{array}$ & {$[62,63,78$} \\
\hline \multirow[t]{6}{*}{ Sheep } & Antelope & Multiple $(\mathrm{d}, \mathrm{k}, \mathrm{q})$ & Yes & Yes & Shared space use & [51] \\
\hline & Badger & GPS & No & Yes & Badger visits to sheep farms & {$[42]$} \\
\hline & Big cat & Radio-telemetry & Yes & Yes & Predation & {$[87,140]$} \\
\hline & \multirow[t]{2}{*}{ Camelid } & Direct visualisation & Yes & Yes & Shared forage sources at different times & {$[79,86]$} \\
\hline & & Multiple $(a, d)$ & No & Yes & Shared forage & {$[130]$} \\
\hline & Canine & GPS & Yes & No & No contacts observed & {$[13]$} \\
\hline
\end{tabular}




\begin{tabular}{|c|c|c|c|c|c|c|}
\hline \multirow[t]{14}{*}{ Livestock } & \multirow[t]{3}{*}{ Wildlife } & \multirow[t]{2}{*}{ Method(s)* } & \multicolumn{2}{|c|}{$\begin{array}{l}\text { Type of contact } \\
\text { recorded }\end{array}$} & \multirow[t]{2}{*}{$\begin{array}{l}\text { Examples of the types of contact(s) reported between each livestock and wildlife } \\
\text { species }\end{array}$} & \multirow[t]{2}{*}{ Referen } \\
\hline & & & Direct & Indirect & & \\
\hline & & Radio-telemetry & No & Yes & Jackal visits to sheep farms & {$[120]$} \\
\hline & Chimpanzee & Direct visualisation & Yes & No & No contacts observed & {$[57]$} \\
\hline & \multirow[t]{2}{*}{ Deer } & Camera & Yes & Yes & No contacts observed & [90] \\
\hline & & Direct visualisation & Yes & Yes & Deer and sheep within five metres of each other & {$[80]$} \\
\hline & Hyena & Multiple $(d, r)$ & Yes & Yes & Predation events & {$[81]$} \\
\hline & Kangaroo & Radio-telemetry & No & Yes & Kangaroo visits to sheep farms & {$[122]$} \\
\hline & Not specified & Camera & No & Yes & Presence on pasture of predators not associated with livestock predation & {$[112]$} \\
\hline & \multirow[t]{2}{*}{ Sheep/Goat } & Direct visualisation & Yes & Yes & Chamois and ibex in close proximity to domestic sheep and sharing pasture & {$[74,85]$} \\
\hline & & Radio-telemetry & No & Yes & Unspecified contact & {$[50]$} \\
\hline & \multirow[t]{3}{*}{ Wild pig } & Activity signs & No & Yes & Wild boar foraging on sheep pasture & {$[36]$} \\
\hline & & Camera & Yes & Yes & No contacts observed & [90] \\
\hline & & Questioning & Yes & Yes & Predation and presence on sheep farms & [88] \\
\hline
\end{tabular}

*Some studies used multiple methods combining variations of activity signs (a), cameras (c), Direct visualisation (d), GPS (g),

3 literature review and expert knowledge elicitation $(k)$, models $(m)$, pathogen monitoring $(p)$, proximity loggers (l), questioning (q) and radio-telemetry $(r)$.

"Where modelling alone is reported, empirical data was used that was not specifically wildlife-livestock contact data. For example, using data on cattle grazing habits to model the frequency of contact with badger faeces on pasture. 